\title{
Excitotoxicity and genetics of amyotrophic lateral sclerosis: effects of intracellular calcium accumulation on proteins encoded by the major genes underlying the disease
}

Giovanni DE MARCo ( $\square$ giovanni.demarco@unito.it )

University of Turin Department of Neurosciences: Universita degli Studi di Torino Dipartimento di Neuroscienze https://orcid.org/0000-0002-3966-8695

Annarosa Lomartire University of Turin: Universita degli Studi di Torino Umberto Manera University of Turin: Universita degli Studi di Torino Antonio Canosa University of Turin: Universita degli Studi di Torino

Maurizio Grassano University of Turin: Universita degli Studi di Torino

Federico Casale

University of Turin: Universita degli Studi di Torino

\section{Giuseppe Fuda}

University of Turin: Universita degli Studi di Torino

\section{Paolina Salamone}

Ospedale Molinette: Azienda Ospedaliero Universitaria Citta della Salute e della Scienza di Torino

\section{Maria Teresa Rinaudo}

University of Turin: Universita degli Studi di Torino

\section{Sebastiano Colombatto}

University of Turin: Universita degli Studi di Torino

\section{Cristina Moglia}

University of Turin: Universita degli Studi di Torino

Adriano Chiò

University of Turin: Universita degli Studi di Torino

\section{Andrea Calvo}

University of Turin: Universita degli Studi di Torino 
Keywords: amyotrophic lateral sclerosis (ALS), calcium, calpains, caspases, autophagy

Posted Date: February 15th, 2021

DOI: https://doi.org/10.21203/rs.3.rs-220372/v1

License: (c) (1) This work is licensed under a Creative Commons Attribution 4.0 International License. Read Full License

Version of Record: A version of this preprint was published at Scientific Reports on January 10th, 2022. See the published version at https://doi.org/10.1038/s41598-021-04267-8. 


\section{Abstract}

The aetiology of Amyotrophic Lateral Sclerosis (ALS), a fatal and incurable disease caused by motor neuron degeneration, is still poorly understood. The discovery of genetic forms of ALS helped to shed light on the mechanisms underlying this pathology, but also showed how complex these mechanisms are. Excitotoxicity is one of the processes strongly suspected to play a role in motor neuron degeneration in ALS. This process consists in neuron damage due to excessive intake of calcium ions $\left(\mathrm{Ca}^{2+}\right)$ by the cell. This study aims to find a relationship between the proteins coded by the most relevant genes associated with ALS and excitotoxicity. In detail, the profile of eight proteins (TDP-43, C9ORF72, p62/SQSTM1, matrin3, VCP, FUS, SOD1 and profilin-1), was analysed in three different cell types induced to raise their cytoplasmic amount of $\mathrm{Ca}^{2+}$.

Intracellular $\mathrm{Ca}^{2+}$ accumulation causes a significant decrease in the levels of TDP-43, C9ORF72, matrin3, VCP, FUS, SOD1 and profilin-1 and an increase in p62/SQSTM1. These events are associated to the proteolytic action of two proteases, calpains and caspases, as well as to the activation of autophagy, a process responsible for the degradation and recycling of cytoplasmic components. Interestingly, $\mathrm{Ca}^{2+}$ appears to both favour and hinder autophagy. The discovery of when $\mathrm{Ca}^{2+}$ levels become toxic for the cell, as well as understanding why the physiological processes of calpain proteolysis and autophagy become pathological, may elucidate the mechanisms responsible for ALS and help discover new therapeutic targets.

\section{Introduction}

Amyotrophic Lateral Sclerosis (ALS) is a progressive and fatal disease leading to a rapid degeneration of motor neurons in brain cortex, brain stem and spinal cord, with onset usually in late middle age. Currently, there are neither reliable biomarkers nor effective pharmacological treatments for the disease and its pathogenesis is still poorly understood. The discovery of genetic aetiology in some ALS patients helped to shed light on motor neurons degeneration. However, ALS cases linked to genetic mutations are less than $10-15 \%$ and these mutations affect more than 30 genes encoding for proteins that have disparate functions [1, 2]. In fact, some of these proteins act by binding DNA and/or RNA [TAR DNA binding protein43 (TDP-43), fused in sarcoma/translocated in liposarcoma (FUS), matrin-3 [3-5]]; some retain enzymatic activity [Cu/Zn superoxide dismutase 1 (SOD1), and valosin-containing protein (VCP) [6, 7]]; others are implicated in protein degradation (p62/sequestosome-1) [8], contribute to the formation of cytoskeleton (profilin-1) [9] or regulate intracellular trafficking pathways [chromosome 9 open reading frame 72 (C9ORF72)] [10].

A lot of evidence supports the hypothesis that excitotoxicity is one of the toxic conditions at the heart of motor neuron degeneration in ALS $[11,12]$. The excitotoxic process consists in neural cell damage caused by an abnormal intake of calcium ions $\left(\mathrm{Ca}^{2+}\right)$ due to the hyperactivation of ionotropic glutamate receptors [13]. This $\mathrm{Ca}^{2+}$ overload may contribute to necrotic or apoptotic cell death through 
mitochondrial dysfunctions, aberrant production of reactive oxygen species and/or endoplasmic reticulum stress [14-16].

The aim of this study is to analyse the effects of excitotoxicity on proteins linked to ALS. In particular, this study assesses the consequences of intracellular $\mathrm{Ca}^{2+}$ overload on the proteins encoded by the most relevant genes associated with ALS, in order to find metabolic processes common to all or most of these proteins. For this purpose, the protein profile of TDP-43, FUS, matrin-3, SOD1, VCP, p62/sequestosome, profilin-1 and C9ORF72, the codifying genes accounting for the majority of ALS genetic forms [1, 2], will be evaluated in three different cell types induced to accumulate $\mathrm{Ca}^{2+}$ in their cytoplasm. Accumulation will be reached by inducing an excessive ion intake or by altering ion flux between intracellular storage structures and cytoplasm.

\section{Materials And Methods}

\section{Reagents}

TDP-43 polyclonal antibody (10782-2-AP) was purchased from ProteinTech Group (Chicago, IL, USA). Matrin-3 (A300-591A), FUS (A300-293A) polyclonal antibodies were from Bethyl Laboratories (Montgomery, TX, USA). C9ORF72 (sc-138763), VCP (sc-20799), SOD1 (sc-11407), PARP (sc-7150) polyclonal antibodies and GAPDH (sc-47724), PFN-1 (sc-137235) monoclonal antibodies, as well as ionomycin calcium salt (sc-3592), thapsigargin (sc-24017) and calpeptin (sc-202516) were obtained from Santa Cruz Biotechnology (Heidelberg, Germany). Anti-mouse IgG (7076P2) and anti-rabbit IgG (7074P2) antibodies conjugated to horseradish peroxidase (HRP) were from Cell Signaling Technology (Leiden, The Netherlands). The active human recombinant caspase set IV (K233-10-25) was purchased from BioVision (Milpitas, CA, USA). Active calpain-1 (208712) and calpain-2 (208718) were from Calbiochem (La Jolla, CA, USA). MINI-PROTEAN TGX 4-15\% precast gel (4561086SP5), TBT RTA Transfer Kit PVDF mini (1704272), Protein molecular markers (SM0671) and the RC DC Protein Assay Kit (500 - 0119) were purchased from Bio-Rad Laboratories (Milan, Italy). The WesternBright Enhanced chemiluminescent substrate (ECL) for HRP (K-12045-D50) was purchased from Advansta (Menlo Park, CA, USA). Nitrocellulose membranes (RPN303D) were purchased from Amersham (Milan, Italy). Lymphoprep ${ }^{\circledR}$ (1114545) was purchased from Axis-Shield (Oslo, Norway). p62 (P0067) and LC3B (L7543) polyclonal antibodies, chloroquine (C6628-25G) as well as high grade versions of all other chemicals and cell media used in this study were purchased from Sigma-Aldrich (Milan, Italy).

\section{Cell culture}

Human neuroblastoma SK-N-BE(2) adhesion cell lines were cultured in RPMI 1640 supplemented with $10 \%$ foetal bovine serum (FBS), sodium pyruvate ( $1 \times$ ) and an antibiotic cocktail $(1 \times)$ at $37^{\circ} \mathrm{C}$ and $5 \% \mathrm{CO}_{2}$. Human carcinoma of the uterine cervix (HeLa) cell lines were cultured in High glucose Dulbecco's Modified Eagle Medium (DMEM) supplemented with 10\% FBS and an antibiotic cocktail (1x). Peripheral blood mononuclear cells (PBMC) from a healthy 35-year old donor (who signed a written informed 
consent) were collected in EDTA-coated tubes as previously described [17] and then incubated in RPMI 1640 supplemented with $10 \%$ FBS and an antibiotic cocktail $(1 \times)$. These three cell types were incubated in multiwell plates at $37^{\circ} \mathrm{C}$ and $5 \% \mathrm{CO}_{2}$.

\section{Treatment of SK-N-BE(2) lysate with calpains}

SK-N-BE(2) cells ( $1 \times 10^{6}$ cells for each sample) were lysed by repeated passage through a $26-\mathrm{G}$ syringe in a reaction solution composed of $50 \mathrm{mM}$ Tris- $\mathrm{HCl} \mathrm{pH} \mathrm{7.5,30} \mathrm{mM} \mathrm{NaCl,} 5 \mathrm{mM}$ DTT and $1 \mathrm{mM}$ calcium chloride and then separately incubated with $2 \mathrm{U}$ of active human calpain-1 or -2 for $10 \mathrm{~min}$ or $180 \mathrm{~min}$ at $37^{\circ} \mathrm{C}$. Furthermore, two samples were treated for $180 \mathrm{~min}$ with both calpain- 1 or -2 and $20 \mathrm{mM}$ calpeptin, a calpain inhibitor. The cleavage reaction was stopped by adding a buffer constituted by $50 \mathrm{mM}$ Tris $\mathrm{pH}$ 6.8, 5\% (w/v) SDS, 8 M deionized urea, and 2\% (v/v) 2-mercaptoethanol and $10 \mathrm{mM}$ EDTA. Samples were then frozen at $-70^{\circ} \mathrm{C}$.

\section{Treatment of SK-N-BE(2) lysate with caspases}

SK-N-BE(2) cells ( $1 \times 10^{6}$ cells for each sample) were lysed by repeated passage through a $26-\mathrm{G}$ syringe in the reaction solution recommended by the manufacturer $(50 \mathrm{mM} H E P E S \mathrm{pH} 7.2,50 \mathrm{mM} \mathrm{NaCl}, 0.1 \%$ CHAPS, $10 \mathrm{mM}$ EDTA, $5 \%$ glycerol and $10 \mathrm{mM} \mathrm{DTT}$ ) and then separately incubated with $2 \mathrm{U}$ of active human caspase- $3,-6,-7$ or -8 for $180 \mathrm{~min}$ at $37^{\circ} \mathrm{C}$. The cleavage reaction was terminated by adding a buffer constituted by $50 \mathrm{mM}$ Tris $\mathrm{pH} 6.8,5 \%(\mathrm{w} / \mathrm{v})$ SDS, $8 \mathrm{M}$ deionized urea, and $2 \%(\mathrm{v} / \mathrm{v}) 2$ mercaptoethanol. Samples were then frozen at $-70^{\circ} \mathrm{C}$.

\section{Cell treatments}

SK-N-BE(2), HeLa cells and PBMC ( $1 \times 10^{5}$ cells for each sample) were treated with ionomycin $(1 \mu \mathrm{M}$ or 5 $\mu \mathrm{M})$ or thapsigargin $(1 \mu \mathrm{M}$ or $5 \mu \mathrm{M})$ for $24 \mathrm{~h}$. Time-dependent experiments were carried out by incubating SK-N-BE(2) with $1 \mu \mathrm{M}$ ionomycin or $1 \mu \mathrm{M}$ thapsigargin for $2 \mathrm{~h}, 8 \mathrm{~h}$ and $24 \mathrm{~h}$. Two-hour treatments of SK$\mathrm{N}-\mathrm{BE}(2)$ with $1 \mu \mathrm{M}$ ionomycin or $1 \mu \mathrm{M}$ thapsigargin were also performed following $2 \mathrm{~h}$ preincubation with $100 \mu \mathrm{M}$ chloroquine.

\section{Western immunoblot analysis}

Samples were subjected to SDS-PAGE using 4-15\% precast gels as previously described [17]. Resolved proteins were then electro-transferred onto nitrocellulose membrane by using the Trans-Blot Turbo Blotting System (Bio-Rad) with the transfer buffer included in the TBT RTA Transfer Kit nitro mini supplemented with $20 \%(\mathrm{v} / \mathrm{v})$ ethanol. Membranes were blocked with $2 \%$ bovine serum albumin (BSA) in a TBST buffer consisting of $0.02 \mathrm{M}$ Tris- $\mathrm{HCl} \mathrm{pH} \mathrm{7.6,0.14} \mathrm{M} \mathrm{NaCl}$, and 0.02\% (v/v) Tween 20.

Membranes were then exposed to different antibodies in in TBST buffer with 5\% BSA. Next, membranes were washed with TBST buffer, incubated with $15 \mathrm{ng} / \mathrm{ml}$ of appropriate HRP-conjugated secondary antibodies at $4^{\circ} \mathrm{C}$, washed again and then exposed to the enhanced chemiluminescence HRP substrate. The immunostained bands were visualized using a C-DiGit@ Blot Scanner gel imaging system and Image Studio $^{\text {TM }}$ software ver 5.0 (LI-COR, Bad Homburg, Germany). When longer exposures were required, bands were detected using Amersham Hyperfilm ECL (GE Healthcare, Little Chalfont, UK). 


\section{Statistical analysis}

Statistical analyses were performed using SPSS software ver. 17.0 (IBM, Armonk, NY, USA). Data were analysed using the Student's $t$ test. Significant differences were set at $p<0.05$.

\section{Results}

\section{Protein cleavage by calpains and caspases}

Firstly, we investigated whether the proteins linked to ALS considered in this study are substrate of two of the major classes of proteases activated by intracellular $\mathrm{Ca}^{2+}$ overload, i.e. calpains and caspases [18, 19]. To this aim, whole lysates of SK-N-BE(2) cells were treated with active recombinant human calpains1 and -2 or active recombinant human caspases $-3,-6,-7$ and -8 .

\section{TDP-43}

Western immunoblot analysis showed that TDP-43 is cleaved by calpains-1 and - 2 (Fig. 1, Table 1). In fact, in lysates treated with calpains, a marked decrease in the full-length protein was accompanied by the formation of at least four fragments with a molecular mass of about 36, 32, 25 and $18 \mathrm{kDa}$. These results are in keeping with previous observations in which TDP-43 calpain products of $36,32,25 \mathrm{kDa}$ are referred to correspond to the amino acid sequences 1-324, 1-286, 1-243, respectively [20]. 
Table 1

Calpains and caspases involved in the proteolysis of proteins codified by genes linked to ALS

\begin{tabular}{|c|c|c|c|c|c|c|}
\hline & calpain-1* & calpain-2* & caspase-3 & caspase -6 & caspase-7 & caspase-8 \\
\hline TDP-43 & ++++ & +++ & +++ & ++++ & ++++ & +++ \\
\hline C9ORF72 & ++++ & ++++ & + & ++ & ++ & +++ \\
\hline p62 & ++++ & ++++ & ++ & ++++ & ++ & ++++ \\
\hline MATR3 & ++++ & ++++ & ++ & ++++ & ++++ & ++++ \\
\hline VCP & +++ & + & - & ++ & - & ++ \\
\hline FUS & ++++ & ++++ & ++ & +++ & +++ & +++ \\
\hline SOD1 & - & - & - & - & - & - \\
\hline PFN1 & - & - & - & - & - & - \\
\hline \multicolumn{7}{|c|}{$*=$ at 10 minutes of treatment } \\
\hline \multicolumn{7}{|c|}{$-=$ no decrease in full-length protein $(\leq 5 \%)$} \\
\hline \multicolumn{7}{|c|}{$\begin{array}{l}+=5 \%<\text { decrease in full-length protein } \leq 10 \% \text { or }<5 \% \text { decrease in full-length protein with visible } \\
\text { cleavage products }\end{array}$} \\
\hline \multicolumn{7}{|c|}{$++=10 \%<$ decrease in full-length protein $\leq 50 \%$} \\
\hline \multicolumn{7}{|c|}{$+++=50 \%<$ decrease in full-length protein $\leq 90 \%$} \\
\hline \multicolumn{7}{|c|}{$++++=$ decrease in full-length protein $>90 \%$} \\
\hline
\end{tabular}

As previously observed in studies performed by us [21] and others [22-26], TDP-43 is a substrate of caspases-3, $-6,-7$ and -8 (Fig. 2, Table 1). The most important fragments generated by caspase cleavage have a molecular mass of 35 and $25 \mathrm{kDa}$. The first one corresponds to the amino acid sequence $90-414$ at the $\mathrm{C}$-terminus of the protein; the second one should be the 220-414 proteolytic product described by Zhang et al [26] or the 170-414 fragment reported by us and others [21, 27, 28].

\section{C9ORF72}

The C9ORF72 antibody used in our study recognized a band of approximately $55 \mathrm{kDa}$, consistent with the predicted molecular mass of the protein. After 10 minutes of treatment with calpains- 1 or -2 , this band completely disappeared and, in parallel, two proteolytic products at $\approx 45$ and $25 \mathrm{kDa}$ emerged (Fig. 1, Table 1).

Treatment of the cell lysate with caspases $-3,-6$ or -7 caused a decrease in the amount of full-length protein of less than $50 \%$. The decrement in the full-length protein after treatment with caspase- 8 was of slightly more than $50 \%$ (Fig. 2, Table 1). 


\section{p62/sequestosome-1}

p62 was already completely degraded at 10 minutes of treatment with calpains-1 or -2 (Fig. 1, Table 1). The protein was also a good substrate for caspases- 6 and -8 and, to a lesser extent, for caspases- 3 and -7 (Fig. 2, Table 1).

All these findings are in agreement with a previous study [29].

\section{Matrin-3}

Calpains- 1 and -2 had already fully degraded matrin-3 at 10 minutes of treatment (Fig. 1, Table 1). The matrin-3 antibody barely identified some proteolytic fragments, of which the most visible had a molecular mass of $\approx 70,25$ and $15 \mathrm{kDa}$ (Fig. 1).

Matrin-3 was also a substrate for caspases-3, $-6,-7$ and -8 . In fact, treatment with the three latter caspases determined an almost complete loss of the full-length protein (Fig. 2, Table 1). This loss was associated with the formation of a fragment at about $20 \mathrm{kDa}$ that was detectable also following exposure to caspase-3 (Fig. 2). These results overlap with those reported by Valencia and colleagues [30]. According to their observations, the $\approx 20 \mathrm{kDa}$ fragment observed by us is consistent with the $681-847 \mathrm{C}$ terminal fragment generated by caspase cleavage at the consensus site DETD ${ }^{680}$.

\section{VCP}

VCP was subjected to degradation by both calpains, although cleavage appeared to be slower by calpain2 than by calpain-1. Interestingly, treatment with calpain-2 at 10 minutes did not determine any appreciable decrease in the full-length protein, but gave rise to an evident proteolytic band at $\approx 50 \mathrm{kDa}$ (Fig. 1, Table 1). It is conceivable that this proteolytic fragment is better recognized than the full-length protein by the antibody used.

Only caspases- 6 and - 8 were seen to cleave VCP, as they caused a slight decrease in the full-length protein paralleled by the generation of a proteolytic fragment at about $70 \mathrm{kDa}$ (Fig. 2, Table 1). These findings are in agreement with a previous paper which reported that the cleavage by the two active caspases occurs at the consensus site VAPD ${ }^{179}$ [31].

\section{FUS}

Full-length FUS was completely degraded at 10 minutes of incubation with either calpains-1 or -2 (Fig. 1, Table 1). The protein degradation was accompanied by the formation of various proteolytic products with a molecular mass ranging from few $\mathrm{kDa}$ less than the full-length protein to $\approx 20 \mathrm{kDa}$. The most evident of these fragments had a molecular mass of $\approx 40 \mathrm{kDa}$ (Fig. 1).

Exposure to caspases-3, $-6,-7$ and -8 was followed by a decrease in the full-length protein (Fig. 2, Table 1). However, identification of the caspase-proteolytic products was difficult with the FUS antibody used (Fig. 2). 


\section{SOD1}

Neither the calpains nor the caspases here considered induced an appreciable decrease in SOD1 (Figs. 1, 2, Table 1).

\section{Profilin-1}

Neither the calpains nor the caspases here considered induced an appreciable decrease in profilin-1 (Figs. 1, 2, Table 1).

\section{Evaluation of protein profiles in cells treated with ionomycin or thapsigargin}

The profile of the proteins considered in the study was then evaluated in cells induced to accumulate $\mathrm{Ca}^{2+}$ in their cytoplasm. To this aim, three different cell types, SK-N-BE(2), HeLa and PBMC, were treated with ionomycin or thapsigargin. Ionomycin is a $\mathrm{Ca}^{2+}$ ionophore that triggers intracellular $\mathrm{Ca}^{2+}$ overload through an excessive ion intake from the extracellular environment [32]. Thapsigargin is a sarcoplasmic/endoplasmic reticulum $\mathrm{Ca}^{2+}$-ATPase inhibitor that raises the concentration of cytosolic $\mathrm{Ca}^{2+}$ by blocking the ion re-uptake in the intracellular storage structures [33].

\section{TDP-43}

Exposure of SK-N-BE(2) cells to ionomycin gave rise to the formation of fragments with a molecular mass of $\approx 36,32$ and $25 \mathrm{kDa}$ (Fig. 3), which are similar to those observed in vitro following treatment with calpains (see above). The decrease in the full-length protein amounted to about $35 \%$ and $45 \%$ for treatment with $1 \mu \mathrm{M}$ and $5 \mu \mathrm{M}$, respectively. Incubation with thapsigargin was followed by the formation of the same 35 and $25 \mathrm{kDa}$ fragments detected in vitro after treatment with caspases. Additionally, the 32 $\mathrm{kDa}$ band typical of in vitro calpain treatment was appreciable, although barely, through $1 \mu \mathrm{M}$ thapsigargin exposure (Fig. 3). The decrease in the full-length protein was of $30 \%$ and $75 \%$ after treatment with $1 \mu \mathrm{M}$ and $5 \mu \mathrm{M}$, respectively.

In HeLa cells, incubation with the two ionomycin concentrations mentioned above did not cause an appreciable decrease in the full-length protein, nor did it trigger the formation of the calpain-dependent fragments. Instead, the effects of incubation with thapsigargin at the two previously mentioned concentrations fully overlapped with the ones observed in SK-N-BE(2) cells (Figs. 3, 5).

In PBMC, the effects of the treatment with ionomycin were the same as the ones obtained in SK-N-BE(2) cells. However, the treatment of PBMC with thapsigargin triggered the formation of calpain-dependent fragments, instead of the caspase proteolytic products observed in SK-N-BE(2) cells (Figs. 3, 5). Thus, in PBMC treatments with both ionomycin and thapsigargin induce cleavage of TDP-43 by calpain. 
Incubation of SK-N-BE(2) cells with ionomycin was associated with a marked decrease in full-length C9ORF72 (Fig. 3) of about $67 \%$ and $90 \%$ for treatment with $1 \mu \mathrm{M}$ and $5 \mu \mathrm{M}$, respectively (Fig. 4). No cleavage products were identified (Fig. 3).

The decrease in C9ORF72 was of approximately 35\% and 65\% in cells exposed to $1 \mu \mathrm{M}$ and $5 \mu \mathrm{M}$ of thapsigargin, respectively. Here too, proteolytic products were hardly appreciable. (Figs. 3, 4).

The C9ORF72 profile found in HeLa cells was very similar to the one obtained in SK-N-BE(2) cells with ionomycin or thapsigargin treatment (Figs. 3,5 ).

In untreated PBMC, the intensity of the full-length C90RF72 band was weaker than that at $\approx 45 \mathrm{kDa}$, with the latter being compatible with one of the proteolytic products caused by calpain (see above). The fulllength C9ORF72 band was no longer appreciable in cells incubated with the highest concentration of ionomycin or thapsigargin here applied. The $\approx 45 \mathrm{kDa}$ proteolytic product was detected in all types of treatment (Fig. 5).

\section{p62/sequestosome-1}

Treatment of SK-N-BE(2) cells with $1 \mu \mathrm{M}$ ionomycin caused an increase in the protein level of about $30 \%$ compared to untreated cells. Incubation with $5 \mu \mathrm{M}$ ionomycin resulted in $\mathrm{a} \approx 30 \%$ decrease in the protein, although this percentage is not significant. Treatment with $1 \mu \mathrm{M}$ thapsigargin doubled the level of the protein. In cells exposed to $5 \mu \mathrm{M}$ thapsigargin, the amount of p62/sequestosome- 1 was similar to that observed in untreated cells (Figs. 3, 4).

The p62/sequestosome-1 profile recorded in HeLa cells was very similar to that obtained in SK-N-BE(2) cells with ionomycin or thapsigargin treatment (Figs. 3, 5).

With respect to untreated PBMC, the level of p62/sequestosome-1 remained approximately unaltered in cells exposed to $1 \mu \mathrm{M}$ ionomycin, whereas it decreased following treatment with $1 \mu \mathrm{M}$ thapsigargin. The protein was no longer detected in cells incubated with the highest concentration of ionomycin or thapsigargin here applied (Fig. 5).

\section{Matrin-3}

Exposure of SK-N-BE(2) cells to ionomycin led to a decrease in matrin-3 of about $50 \%$ and $80 \%$ for treatment with $1 \mu \mathrm{M}$ and $5 \mu \mathrm{M}$, respectively. In both cases, $\mathrm{a} \approx 70 \mathrm{kDa}$ product, compatible with the one observed in vitro following treatment with calpains, was detected, although faintly (Figs. 3, 4). Incubation with thapsigargin was followed by a decrement in the protein of $55 \%$ and $85 \%$ after treatment with $1 \mu \mathrm{M}$ and $5 \mu \mathrm{M}$, respectively (Figs. 3, 4). The $\approx 20 \mathrm{kDa}$ caspase-dependent fragment found in vitro was appreciable after incubation with the highest concentration of thapsigargin here used (Fig. 3).

The decrease in matrin-3 in HeLa cells exposed to ionomycin or thapsigargin closely reproduced the one described above for SK-N-BE(2) cells (Fig. 5). 
In PBMC, both ionomycin and thapsigargin, at the highest concentrations used, determined a dramatic decrease in matrin-3. The $\approx 70 \mathrm{kDa}$ calpain-dependent product was recorded in cells treated with $1 \mu \mathrm{M}$ and $5 \mu \mathrm{M}$ ionomycin, as well as with $5 \mu \mathrm{M}$ thapsigargin (Fig. 5).

\section{VCP}

Exposure of SK-N-BE(2) cells to $1 \mu \mathrm{M}$ and $5 \mu \mathrm{M}$ ionomycin induced a decrease in VCP of about $40 \%$ and $78 \%$, respectively. $A \approx 50 \mathrm{kDa}$ fragment, consistent with a calpain-dependent cleavage and probably better recognized by the VCP antibody here used than the full-length protein (see above), was clearly detected in cells treated with $5 \mu \mathrm{M}$ ionomycin (Figs. 3,4). The decrease in VCP in SK-N-BE(2) cells treated with $1 \mu \mathrm{M}$ and $5 \mu \mathrm{M}$ thapsigargin was of about $14 \%$ (not significant) and $30 \%$, respectively (Figs. 3,4 ). The $\approx 50 \mathrm{kDa}$ calpain-dependent fragment was barely detectable in cells incubated with $1 \mu \mathrm{M}$ ionomycin (Fig. 3).

In HeLa cells, a marked decrease in VCP was observed with both concentrations of ionomycin. Only the highest concentration of thapsigargin induced an appreciable decrease in the protein level. Proteolytic products of VCP were poorly detected following all treatments (Fig. 5).

In PBMC, all treatments applied caused a slight decrease in VCP. The $\approx 50 \mathrm{kDa}$ calpain-dependent fragment was clearly evident in cells exposed to the highest concentrations of ionomycin or thapsigargin (Fig. 5).

\section{FUS}

Treatment of SK-N-BE(2) cells with ionomycin or thapsigargin caused a decrease in the protein level of about $60 \%$ at $1 \mu \mathrm{M}$ and $90 \%$ at $5 \mu \mathrm{M}$, while thapsigargin induced a decrease of $50 \%$ at $1 \mu \mathrm{M}$ and $75 \%$ at 5 $\mu \mathrm{M}$ (Figs. 3, 4). Among the calpain-dependent fragments observed in in vitro experiments (see above), only one with a molecular mass of few kDa smaller than the full-length protein was detected. This fragment was visible in cells treated with $1 \mu \mathrm{M}$ and $5 \mu \mathrm{M}$ ionomycin as well as with $1 \mu \mathrm{M}$ thapsigargin (Figs. 3, 4).

HeLa cells, exposed to $1 \mu \mathrm{M}$ or $5 \mu \mathrm{M}$ ionomycin as well as to $5 \mu \mathrm{M}$ thapsigargin, reproduced the decrement in FUS observed in SK-N-BE(2) cells (Figs. 3, 5), while proteolytic products were not detected in treated HeLa cells (Fig. 5).

In PBMC, both ionomycin and thapsigargin elicited an almost complete loss of FUS at the highest concentrations used. Such a loss was paralleled by the formation of a fragment compatible with the calpain-dependent one observed in treated SK-N-BE(2) cells (Figs. 3, 5).

\section{SOD1}

Exposure of SK-N-BE(2) cells to ionomycin led to a decrease in SOD1 of about $68 \%$ and $97 \%$ for treatment with $1 \mu \mathrm{M}$ and $5 \mu \mathrm{M}$, respectively. Incubation with thapsigargin was followed by a decrease in the protein 
level of about $54 \%$ and $84 \%$ after treatments with $1 \mu \mathrm{M}$ and $5 \mu \mathrm{M}$, respectively. No proteolytic products were detected in cells exposed to either of the compounds (Fig. 3).

In HeLa cells as well as in PBMC treated with ionomycin or thapsigargin the SOD1 profile was similar to that obtained in similarly treated SK-N-BE(2) cells (Figs. 3, 5).

\section{Profilin-1}

Exposure of SK-N-BE(2) cells to ionomycin at $1 \mu \mathrm{M}$ and $5 \mu \mathrm{M}$ led to a decrease in profilin- 1 of about $73 \%$ and $93 \%$ respectively. Incubation with thapsigargin at $1 \mu \mathrm{M}$ and $5 \mu \mathrm{M}$ was followed by a decrease in the protein level of about $57 \%$ and $85 \%$ respectively (Figs. 3,4 ). Proteolytic products were not detected in treated cells (Fig. 3).

The profilin-1 profile in HeLa cells as well as in PBMC incubated with ionomycin or thapsigargin was similar to that found in SK-N-BE(2) cells (Figs. 3, 5).

\section{Other proteins}

The following proteins are not coded by genes linked to ALS, but an evaluation of their profile could be useful to identify pathways involving proteins directly linked to ALS.

\section{PARP-1}

PARP-1 is a marker of apoptosis. In fact, during the apoptotic process, caspases cause PARP-1 cleavage, producing an $89 \mathrm{kDa}$ C-terminal fragment [34]. Treatment of SK-N-BE(2) cells with ionomycin at the two concentrations here applied induced a decrease in the protein level, but no caspase-dependent fragment was detected. On the contrary, such a fragment was observed in the same cell line when exposed to thapsigargin at $1 \mu \mathrm{M}$ and was even more evident, together with a drastic loss of the full-length protein, when treated with $5 \mu \mathrm{M}$ thapsigargin (Fig. 6).

\section{LC3}

Conversion of LC3 from the non-lipidated (LC3-I) to the lipidated (LC3-II) form, with the latter being detectable at a lower mass than the former, is widely used to monitor autophagy [35]. In untreated SK-N$\mathrm{BE}(2)$ cells, the LC3-I/LC3-II ratio was $>1$, whereas it was $<1$ when treated with ionomycin or thapsigargin. The higher the concentration of these compounds, the lower the ratio. Furthermore, treatment with ionomycin or thapsigargin was associated with a decrease in the total amount (LC3-I + LC3-II) of LC3 (Fig. 6).

\section{Time-dependent treatments and preincubation with chloroquine}

For a better comprehension of the pathways triggered by intracellular $\mathrm{Ca}^{2+}$ overload and the consequent effects on the proteins linked to ALS, the profile of some of the latter was analysed in SK-N-BE(2) cells 
exposed for 2, 8 and $24 \mathrm{~h}$ to ionomycin or thapsigargin at the lowest of the concentrations previously applied. Furthermore, preincubation with chloroquine, an inhibitor of the autophagic process, was performed for 2-h treatments with ionomycin or thapsigargin.

\section{TDP-43}

TDP-43 calpain-dependent fragments were detected already at $2 \mathrm{~h}$ of ionomycin exposure. Instead, the 35 $\mathrm{kDa}$ caspase-dependent fragment was appreciable only after $24 \mathrm{~h}$ of thapsigargin treatment (Fig. 7a). Preincubation with chloroquine did not affect the cleavage of the protein by calpains (Fig. 7b).

\section{p62/sequestosome-1}

In untreated cells, p62/sequestosome-1 levels decreased during the time interval considered (2-24 h). Treatment with ionomycin caused an even more drastic decrease in the protein level at $2 \mathrm{~h}$ compared to untreated cells. However, it raised the overall protein amount in the time interval considered $(2-24 \mathrm{~h})$. This profile was closely reproduced by thapsigargin treatment (Fig. 7a).

Pretreatment with chloroquine resulted in an increase in p62/sequestosome-1 levels in both ionomycinand thapsigargin-treated cells (Fig. 7b).

\section{PARP-1}

The decrement of PARP-1 induced by ionomycin was already appreciable after $2 \mathrm{~h}$ of treatment. The 89 $\mathrm{kDa}$ caspase-dependent proteolytic product was observed after $24 \mathrm{~h}$ of thapsigargin treatment (Fig. 7a).

\section{LC3}

In untreated cells, the LC3-I/LC3-II ratio was > 1 and did not significantly vary during the time the measurements were taken. Incubation with ionomycin for $2 \mathrm{~h}$ was followed by a decrease in the total amount of LC3 as well as by a decrease in the LC3-I/LC3-II ratio compared to the ratio calculated in untreated cells. As reported above, the ratio was $<1$ in cells treated with ionomycin for $24 \mathrm{~h}$. The results obtained in cells incubated with thapsigargin overlapped with the ones found in cells incubated with ionomycin (Fig. 7a). Preincubation with chloroquine prevented the decrease in the total amount of LC3 and favoured the formation of the lipidated form of the protein both in ionomycin- and thapsigargintreated cells (Fig. 7b).

\section{Profilin-1}

A drastic decrease in the protein was already clearly evident in cells incubated with ionomycin for $2 \mathrm{~h}$. Treatment with thapsigargin replicated, although to a lesser extent, the decrease in the protein level detected in cells treated with ionomycin (Fig. 7a). Preincubation with chloroquine partially prevented the loss of the protein caused by ionomycin treatment and totally blocked the decrease in the protein amount determined by thapsigargin treatment (the analysis of SOD1 gave a similar result, Fig. 7b). 


\section{Discussion}

The discovery of genes associated with ALS is in constant progress and undoubtedly important for the comprehension of the causes underlying the disease. However, the numerous functions of the proteins coded by these genes shows how complex the mechanisms involved in the pathology are. This study attempts to find a link between the proteins coded by the most relevant genes associated with ALS and excitotoxicity, one of the processes strongly suspected to play a role in motor neuron degeneration.

TDP-43 is a protein, coded for by the gene TARDBP [2], that acts as splicing regulator and transcription factor by binding single-stranded DNA and RNA [36]. The importance of TDP-43 is due to the presence of alterations of this protein in motor neurons of most ALS-affected individuals. Alterations consist in abnormal nuclear/cytoplasmic distribution, aggregation to form inclusions, aberrant phosphorylation and ubiquitinylation as well as proteolytic cleavage $[37,38]$. The products of TDP-43 proteolytic degradation are the consequence of the action of caspases $[23,24,26]$ as well as of calpains [20]. The results of this study show that an excessive $\mathrm{Ca}^{2+}$ influx into the cell triggers TDP-43 cleavage by calpains and determines a decrement in the protein level. Cytoplasmic $\mathrm{Ca}^{2+}$ accumulation due to the alteration of intracellular $\mathrm{Ca}^{2+}$ storage structures determines a cleavage of TDP-43 by caspases. The more severe the insult, the more relevant is the TDP-43 decrease and its proteolysis by caspases. This condition causes also a weak cleavage by calpains. The role of TDP-43 fragments in the pathogenesis of ALS is still debated. On the one hand, the propensity of the fragments to aggregate and form inclusions may be a determinant for motor neuron toxicity $[39,40]$. On the other hand, proteolysis of TDP-43 may be an attempt of the cell to attenuate the damage caused by excessive levels of full-length protein $[39,28]$.

C9ORF72 is a component of a protein complex that has guanine nucleotide exchange factor (GEF) activity and regulates endosomal trafficking linked to protein degradation [10]. A mutation of C9ORF72 is the most common genetic cause of ALS [2]. However, this mutation consists in a hexanucleotide repeat within a non-coding region of the gene and thus it is difficult to understand the way in which the genetic alteration affects the protein and, in turn, determines the disease. Our study showed that C9ORF72 is an excellent substrate for calpains and, to a lesser extent, for caspases. An increase in intracellular $\mathrm{Ca}^{2+}$ determines a decrement in the protein amount, which is more evident if caused by an excessive ion influx. It has been demonstrated that the repeat expansion in C9ORF72 is linked to reduced levels of the coded protein in neurons and in other cell types, which has been associated with neurodegeneration [41-43]. This study suggests that the pathological decrease of C9ORF72 caused by the repeat expansion can also be determined by intracellular accumulation of $\mathrm{Ca}^{2+}$.

p62/sequestosome- 1 is a cargo protein that binds to proteins targeted for degradation through autophagy and the ubiquitin-proteasome system $[44,8]$. This study confirmed that p62/sequestosome-1 is a good substrate for calpains and caspases (in particular caspases-6 and - 8) [29]. However, intracellular $\mathrm{Ca}^{2+}$ accumulation, induced either by massive ion intake or by impaired intracellular storage, produces an increase in p62/sequestosome-1 levels. More precisely, high amounts of intracellular $\mathrm{Ca}^{2+}$ determine an initial decrease in the protein amount, which is then followed by accumulation. When 
autophagy occurs, p62/sequestosome- 1 is itself degraded, together with the proteins it carries [8]. Instead, when autophagy is blocked, the levels of p62/sequestosome-1 rise and LC3, another protein linked to autophagy, is converted from non-lipidated to the lipidated form $[45,46]$. Therefore, the levels of p62/sequestosome-1 appear to be modulated by $\mathrm{Ca}^{2+}$ through autophagy rather than proteolysis by calpains and caspases. Interestingly, motor neuron damage has been associated to either a decrement or an increase of p62/sequestosome-1 $[47,48]$.

Matrin-3 is a nuclear protein involved in chromatin organization, DNA replication, transcription, repair, and RNA processing and transport [4]. It shows structural and functional similarities with TDP-43 and can aggregate with the latter to form the neuronal inclusions typical of ALS [49]. Herein, matrin-3 has been revealed to be an excellent substrate for calpains and caspases. Additionally, its levels decrease following intracellular $\mathrm{Ca}^{2+}$ accumulation. In this respect, neurodegeneration has been associated with both increases and decreases in matrin-3 levels [50].

VCP is an ATPase that plays a role in a wide variety of cellular functions including cell signalling, cell cycling, organelle biogenesis and some aspects of intracellular proteolysis, such as autophagy and the ubiquitin proteasome system [51]. VCP mutations may account for $\sim 1-2 \%$ of familial ALS cases [52, 2]. We found that VCP is a substrate for calpains as well as for caspases- 6 and -8 . Furthermore, intracellular $\mathrm{Ca}^{2+}$ increase is responsible for a decrement in the protein amount. Since VCP is involved in several cellular processes, it is likely that its decrement determines cell damage by altering different biological pathways. For example, a loss of VCP hampers protein turnover by interfering with the ubiquitin proteasome system and autophagy [53].

Similarly to TDP-43, FUS is a protein involved in transcription regulation, RNA splicing, RNA transport and DNA repair [54]. Mutations of FUS/TLS gene account for about $4 \%$ of familial ALS cases [2]. This study revealed that FUS is a good substrate for calpains and caspases. In addition, intracellular $\mathrm{Ca}^{2+}$ overload is responsible for a decrease in the protein levels. A loss of FUS in motor neurons has been reported to alter RNA metabolism, cellular morphology and axonal function [55].

SOD1 is an enzyme that converts superoxide radicals to molecular oxygen and hydrogen peroxide, thus providing a defence against oxygen toxicity [56]. Among the several genes associated to ALS, SOD1 was the first identified [57] and is by far the most extensively studied. Our study shows that SOD1 is a substrate for neither calpains nor caspases. However, intracellular $\mathrm{Ca}^{2+}$ accumulation leads to a relevant decrement in the protein levels. This decrement is, at least partially, prevented by an autophagic inhibitor. By determining a decrease in the amount of SOD1, it is reasonable to believe that a $\mathrm{Ca}^{2+}$ overload may cause oxidative stress, another event associated with motor neuron degeneration in ALS.

Profilin-1 is a protein implicated in cytoskeletal dynamics through the regulation of actin polymerization [58]. Mutations of PFN1, the gene coding for profilin-1, account for less than $1 \%$ of ALS cases, but their discovery suggested a new cellular mechanism in the pathogenesis of the disease. Similarly to what observed for SOD1, profilin-1 is a substrate for neither calpains nor caspases, despite the relevant 
decrease caused by intracellular $\mathrm{Ca}^{2+}$ accumulation and partially prevented when autophagy is inhibited. A reduction in the amount of profilin- 1 might damage motor neurons by disrupting their cytoskeletal architecture. In this regard, there is increasing evidence that cytoskeletal defects have a major role in motor neuron diseases [59].

The investigations here reported disclose that elevated intracellular $\mathrm{Ca}^{2+}$ concentrations result in a decrease in the levels of the proteins examined except for p62/sequestosome- 1 . Calpain- and caspasemediated proteolysis as well as autophagy take a part in this decrement (although the involvement of other pathways cannot be ruled out). The predominance of one of the above processes depends on the cell type. In fact, calpain activity was poorly appreciable in a cervical cancer cell line (HeLa), whereas caspase activity was not found in blood mononuclear circulating cells.

Calpains belong to a class of thiol proteases whose catalytic activity is strictly dependent on $\mathrm{Ca}^{2+}[18]$. Here, cytoplasmic $\mathrm{Ca}^{2+}$ accumulation caused by a massive ion influx or, to a smaller extent, by internal storage impairments, was seen to activate calpains. Calpain-1 seems to play a role in the early phase and during progression of ALS [60]. In addition, a selective inhibitor of calpains has been demonstrated to be neuroprotective in a mouse model of ALS [61].

Caspases are a class of thiol proteases essential for apoptosis, a form of programmed cell death [62]. Differently from calpains, caspases are not strictly dependent on $\mathrm{Ca}^{2+}$ for their activity, but $\mathrm{Ca}^{2+}$ is one of the stimuli that trigger the mechanisms that result in the activation of these proteases. A cytoplasmic $\mathrm{Ca}^{2+}$ accumulation caused by internal storage alterations activates, later in time with respect to calpains activation mediated by $\mathrm{Ca}^{2+}$ influx, the apoptotic caspases- 3 and -7 , but not caspase- 6 (i.e. lack of caspase-dependent fragments of VCP). However, activation of caspase- 6 occurs later than that of caspases-3 and - $7[21,63]$ and therefore the consequences of its activity might become appreciable over a longer period of time. An implication of caspases in the neurodegenerative processes underlying ALS has been documented [64-66], although caspase-6 appears to play a neuroprotective role [67].

Autophagy is a degradation/recycling process that plays a wide variety of roles in the cell, including regulation of protein turnover, elimination of unwanted components, defence towards invading microorganisms, and provision of nutrient elements [68]. The link between $\mathrm{Ca}^{2+}$ and autophagy is well documented but controversial. In fact, a rise in intracellular $\mathrm{Ca}^{2+}$ levels can activate but also inhibit the autophagic flux [69]. The findings of this work indicate that intracellular $\mathrm{Ca}^{2+}$ accumulation initially enhances autophagy, but later blocks the process. Accordingly, the agents that increase cytosolic $\mathrm{Ca}^{2+}$ levels block the autophagic flux in its intermediate or even in its latest stages [70,71]. When autophagy is active, all the proteins linked to ALS here considered are degraded. However, the subsequent block of the process is not associated with a recovery of the degraded proteins, with the notable exception of p62/sequestosome-1. A possible explanation is that, in the persistence of intracellular $\mathrm{Ca}^{2+}$ accumulation, the cell attempts to maintain the autophagic activity (even if the process is blocked), thus continuing to synthetize the necessary proteins. At the same time, the synthesis of the proteins degraded 
by autophagy is arrested. Autophagy appears to be an important factor in the pathogenesis of ALS, but its role is extremely complex if not contradictory. In fact, both an excessive and an insufficient autophagic flux has been linked to ALS, and autophagy may either exacerbate or alleviate the disease processes at different stages $[72,73]$.

Calpain-mediated proteolysis, apoptosis and autophagy are tightly connected. In fact, calpains can both regulate the autophagic flux $[69,74]$ and activate or inactivate caspases $[75,76]$. Furthermore, a block of autophagy can trigger apoptosis [77-79]. Moreover, some of the proteins linked to ALS here analysed, such as VCP and C9ORF72 (besides p62/sequestosome-1), play themselves an important role in the control of the processes that determine their degradation [80-82].

Thus, accumulation of $\mathrm{Ca}^{2+}$ in the cell, which is likely to be at the core of motor neuron degeneration in ALS, causes the alteration of a complex balance that leads to the activation of proteolytic processes targeting proteins coded by genes linked to the pathology (Fig. 8). A better understanding of when $\mathrm{Ca}^{2+}$ levels become toxic for the cell as well as how and why calpain proteolysis and autophagy, which are physiological processes, become pathological may elucidate the mechanisms responsible for ALS and help discover novel biomarkers and therapeutic targets.

\section{Declarations}

\section{Acknowledgments}

The authors thank the CRESLA Group: Martina Arcari, Alessandro Bombaci, Maura Brunetti, Sara Cabras, Paolo Cugnasco, Margherita Daviddi, Silvia Giusiano, Barbara lazzolino, Antonio Ilardi, Enrico Matteoni, Francesca Palumbo, Laura Peotta, Luca Solero, Maria Claudia Torrieri, Rosario Vasta.

\section{Funding}

This work was in part supported by the Italian Ministry of University and Research (Progetti di Ricerca di Rilevante Interesse Nazionale, PRIN, grant 2015LFPNMN and 2017SNW5MB), the Italian Ministry of Health (Ricerca Sanitaria Finalizzata, RF-2016-02362405 and RF-2018-12365614), the European Commission's Health Seventh Framework Programme (FP7/2007-2013 under grant agreement 278611), and the Associazione Piemontese per l'Assistenza alla SLA (APASLA), Torino

This study was performed under the Department of Excellence 2018-2022 grant of the Italian Ministry of Education, University and Research to the "Rita Levi Montalcini" Department of Neuroscience, University of Turin, Turin, Italy.

Funding sources had no role in design and conduct of the study, collection, management, analysis, and interpretation of the data, preparation, review, or approval of the manuscript, and decision to submit the manuscript for publication.

\section{Conflict of interests}


Giovanni De Marco, Annarosa Lomartire, Umberto Manera, Antonio Canosa, Maurizio Grassano, Federico Casale, Giuseppe Fuda, Paolina Salamone, Maria Teresa Rinaudo, Sebastiano Colombatto, Cristina Moglia: no competing interest.

Andrea Calvo has received a research grant from Cytokinetics.

Adriano Chiò serves on scientific advisory boards for Mitsubishi Tanabe, Roche, Biogen, Cytokinetics, and AveXis, and has received a research grant from Italfarmaco.

\section{Consent to participate and ethics approval}

The subject whose PBMC were analysed in this study signed a written informed consent before blood drawn as a part of a study supported by the European Commission's Health Seventh Framework Programme (FP7/2007-2013 under grant agreement 278611) and approved by the Ethics Committee of the Azienda Ospedaliero-Universitaria Città della Salute e della Scienza di Torino in accordance with the ethical standards laid down in the 1964 Declaration of Helsinki and its later amendments.

\section{Consent for publication}

All authors have read and approved the submitted version of the manuscript.

\section{Availability of data and material (data transparency)}

All data generated or analysed during this study are included in this published article.

\section{Code availability (software application or custom code)}

Not applicable.

\section{Author contributions}

Giovanni De Marco designed the study, performed the experiments and generated the data along with Annarosa Lomartire. Giovanni De Marco, Annarosa Lomartire and Maria Teresa Rinaudo analysed and interpreted all the results. Sebastiano Colombatto participated in discussion of results and design of some experiments. Giovanni De Marco, Annarosa Lomartire, Maria Teresa Rinaudo and Umberto Manera wrote the manuscript. Umberto Manera, Maurizio Grassano, Federico Casale aided in interpreting the results. Antonio Canosa, Maurizio Grassano, Federico Casale, Giuseppe Fuda, Paolina Salamone and Cristina Moglia worked on the manuscript. Andrea Calvo and Adriano Chiò obtained funding and supervised the study. All coauthors read and approved the manuscript.

\section{References}

1. Li HF, Wu ZY (2016) Genotype-phenotype correlations of amyotrophic lateral sclerosis. Translational neurodegeneration 5:3. doi:10.1186/s40035-016-0050-8 
2. Renton $A E$, Chio A, Traynor BJ (2014) State of play in amyotrophic lateral sclerosis genetics. Nature neuroscience 17 (1):17-23. doi:10.1038/nn.3584

3. Buratti E, Baralle FE (2008) Multiple roles of TDP-43 in gene expression, splicing regulation, and human disease. Frontiers in bioscience : a journal and virtual library 13:867-878

4. Salton M, Elkon R, Borodina T, Davydov A, Yaspo ML, Halperin E, Shiloh Y (2011) Matrin 3 binds and stabilizes mRNA. PloS one 6 (8):e23882. doi:10.1371/journal.pone.0023882

5. Sama RR, Ward CL, Bosco DA (2014) Functions of FUS/TLS from DNA repair to stress response: implications for ALS. ASN neuro 6 (4). doi:10.1177/1759091414544472

6. Valentine JS, Doucette PA, Zittin Potter S (2005) Copper-zinc superoxide dismutase and amyotrophic lateral sclerosis. Annual review of biochemistry 74:563-593. doi:10.1146/annurev.biochem.72.121801.161647

7. Wang Q, Song C, Li CC (2004) Molecular perspectives on p97-VCP: progress in understanding its structure and diverse biological functions. Journal of structural biology 146 (1-2):44-57. doi:10.1016/j.jsb.2003.11.014

8. Komatsu M, Ichimura Y (2010) Physiological significance of selective degradation of p62 by autophagy. FEBS letters 584 (7):1374-1378. doi:10.1016/j.febslet.2010.02.017

9. Witke W (2004) The role of profilin complexes in cell motility and other cellular processes. Trends in cell biology 14 (8):461-469. doi:10.1016/j.tcb.2004.07.003

10. Farg MA, Sundaramoorthy V, Sultana JM, Yang S, Atkinson RA, Levina V, Halloran MA, Gleeson PA, Blair IP, Soo KY, King AE, Atkin JD (2014) C9ORF72, implicated in amytrophic lateral sclerosis and frontotemporal dementia, regulates endosomal trafficking. Human molecular genetics 23 (13):35793595. doi: $10.1093 / \mathrm{hmg} / \mathrm{ddu} 068$

11. Mitchell JD, Borasio GD (2007) Amyotrophic lateral sclerosis. Lancet 369 (9578):2031-2041. doi:10.1016/S0140-6736(07)60944-1

12. Van Damme P, Dewil M, Robberecht W, Van Den Bosch L (2005) Excitotoxicity and amyotrophic lateral sclerosis. Neuro-degenerative diseases 2 (3-4):147-159. doi:10.1159/000089620

13. Spalloni A, Nutini M, Longone P (2013) Role of the N-methyl-d-aspartate receptors complex in amyotrophic lateral sclerosis. Biochimica et biophysica acta 1832 (2):312-322. doi:10.1016/j.bbadis.2012.11.013

14. Appel SH, Beers D, Siklos L, Engelhardt JI, Mosier DR (2001) Calcium: the Darth Vader of ALS. Amyotrophic lateral sclerosis and other motor neuron disorders : official publication of the World Federation of Neurology, Research Group on Motor Neuron Diseases 2 Suppl 1:S47-54

15. Grosskreutz J, Van Den Bosch L, Keller BU (2010) Calcium dysregulation in amyotrophic lateral sclerosis. Cell calcium 47 (2):165-174. doi:10.1016/j.ceca.2009.12.002

16. Tradewell ML, Cooper LA, Minotti S, Durham HD (2011) Calcium dysregulation, mitochondrial pathology and protein aggregation in a culture model of amyotrophic lateral sclerosis: mechanistic relationship and differential sensitivity to intervention. Neurobiology of disease 42 (3):265-275. doi:10.1016/j.nbd.2011.01.016 
17. De Marco G, Lupino E, Calvo A, Moglia C, Buccinna B, Grifoni S, Ramondetti C, Lomartire A, Rinaudo MT, Piccinini M, Giordana MT, Chio A (2011) Cytoplasmic accumulation of TDP-43 in circulating lymphomonocytes of ALS patients with and without TARDBP mutations. Acta neuropathologica 121 (5):611-622. doi:10.1007/s00401-010-0786-7

18. Khorchid A, Ikura M (2002) How calpain is activated by calcium. Nature structural biology 9 (4):239241. doi:10.1038/nsb0402-239

19. Orrenius S, Zhivotovsky B, Nicotera P (2003) Regulation of cell death: the calcium-apoptosis link. Nature reviews Molecular cell biology 4 (7):552-565. doi:10.1038/nrm1150

20. Yamashita T, Hideyama T, Hachiga K, Teramoto S, Takano J, Iwata N, Saido TC, Kwak S (2012) A role for calpain-dependent cleavage of TDP-43 in amyotrophic lateral sclerosis pathology. Nature communications 3:1307. doi:10.1038/ncomms2303

21. De Marco G, Lomartire A, Mandili G, Lupino E, Buccinna B, Ramondetti C, Moglia C, Novelli F, Piccinini M, Mostert M, Rinaudo MT, Chio A, Calvo A (2014) Reduced cellular $\mathrm{Ca}(2+)$ availability enhances TDP-43 cleavage by apoptotic caspases. Biochimica et biophysica acta 1843 (4):725-734. doi:10.1016/j.bbamcr.2014.01.010

22. Cassel JA, McDonnell ME, Velvadapu V, Andrianov V, Reitz AB (2012) Characterization of a series of 4-aminoquinolines that stimulate caspase-7 mediated cleavage of TDP-43 and inhibit its function. Biochimie 94 (9):1974-1981. doi:10.1016/j.biochi.2012.05.020

23. Li Q, Yokoshi M, Okada H, Kawahara Y (2015) The cleavage pattern of TDP-43 determines its rate of clearance and cytotoxicity. Nature communications 6:6183. doi:10.1038/ncomms 7183

24. Rohn TT (2009) Cytoplasmic inclusions of TDP-43 in neurodegenerative diseases: a potential role for caspases. Histology and histopathology 24 (8):1081-1086. doi:10.14670/HH-24.1081

25. Rutherford NJ, Zhang YJ, Baker M, Gass JM, Finch NA, Xu YF, Stewart H, Kelley BJ, Kuntz K, Crook RJ, Sreedharan J, Vance C, Sorenson E, Lippa C, Bigio EH, Geschwind DH, Knopman DS, Mitsumoto H, Petersen RC, Cashman NR, Hutton M, Shaw CE, Boylan KB, Boeve B, Graff-Radford NR, Wszolek ZK, Caselli RJ, Dickson DW, Mackenzie IR, Petrucelli L, Rademakers R (2008) Novel mutations in TARDBP (TDP-43) in patients with familial amyotrophic lateral sclerosis. PLoS genetics 4 (9):e1000193. doi:10.1371/journal.pgen.1000193

26. Zhang YJ, Xu YF, Dickey CA, Buratti E, Baralle F, Bailey R, Pickering-Brown S, Dickson D, Petrucelli L (2007) Progranulin mediates caspase-dependent cleavage of TAR DNA binding protein-43. The Journal of neuroscience : the official journal of the Society for Neuroscience 27 (39):10530-10534. doi:10.1523/JNEUROSCI.3421-07.2007

27. Nishimoto Y, Ito D, Yagi T, Nihei Y, Tsunoda Y, Suzuki N (2010) Characterization of alternative isoforms and inclusion body of the TAR DNA-binding protein-43. The Journal of biological chemistry 285 (1):608-619. doi:10.1074/jbc.M109.022012

28. Suzuki H, Lee K, Matsuoka M (2011) TDP-43-induced death is associated with altered regulation of $\mathrm{BIM}$ and Bcl-xL and attenuated by caspase-mediated TDP-43 cleavage. The Journal of biological chemistry 286 (15):13171-13183. doi:10.1074/jbc.M110.197483

Page 20/34 
29. Norman JM, Cohen GM, Bampton ET (2010) The in vitro cleavage of the hAtg proteins by cell death proteases. Autophagy 6 (8):1042-1056

30. Valencia CA, Ju W, Liu R (2007) Matrin 3 is a Ca2+/calmodulin-binding protein cleaved by caspases. Biochemical and biophysical research communications 361 (2):281-286. doi:10.1016/j.bbrc.2007.06.156

31. Halawani D, Tessier S, Anzellotti D, Bennett DA, Latterich M, LeBlanc AC (2010) Identification of Caspase-6-mediated processing of the valosin containing protein ( $p 97$ ) in Alzheimer's disease: a novel link to dysfunction in ubiquitin proteasome system-mediated protein degradation. The Journal of neuroscience : the official journal of the Society for Neuroscience 30 (17):6132-6142. doi:10.1523/JNEUROSCI.5874-09.2010

32. Liu C, Hermann TE (1978) Characterization of ionomycin as a calcium ionophore. The Journal of biological chemistry 253 (17):5892-5894

33. Lytton J, Westlin M, Hanley MR (1991) Thapsigargin inhibits the sarcoplasmic or endoplasmic reticulum Ca-ATPase family of calcium pumps. The Journal of biological chemistry 266 (26):1706717071

34. Soldani C, Scovassi Al (2002) Poly(ADP-ribose) polymerase-1 cleavage during apoptosis: an update. Apoptosis : an international journal on programmed cell death 7 (4):321-328

35. Mizushima N, Yoshimori T (2007) How to interpret LC3 immunoblotting. Autophagy 3 (6):542-545

36. Ratti A, Buratti E (2016) Physiological functions and pathobiology of TDP-43 and FUS/TLS proteins. Journal of neurochemistry 138 Suppl 1:95-111. doi:10.1111/jnc.13625

37. Arai T, Hasegawa M, Akiyama H, Ikeda K, Nonaka T, Mori H, Mann D, Tsuchiya K, Yoshida M, Hashizume Y, Oda T (2006) TDP-43 is a component of ubiquitin-positive tau-negative inclusions in frontotemporal lobar degeneration and amyotrophic lateral sclerosis. Biochemical and biophysical research communications 351 (3):602-611. doi:10.1016/j.bbrc.2006.10.093

38. Neumann M, Sampathu DM, Kwong LK, Truax AC, Micsenyi MC, Chou TT, Bruce J, Schuck T, Grossman M, Clark CM, McCluskey LF, Miller BL, Masliah E, Mackenzie IR, Feldman H, Feiden W, Kretzschmar HA, Trojanowski JQ, Lee VM (2006) Ubiquitinated TDP-43 in frontotemporal lobar degeneration and amyotrophic lateral sclerosis. Science 314 (5796):130-133. doi:10.1126/science. 1134108

39. Berning BA, Walker AK (2019) The Pathobiology of TDP-43 C-Terminal Fragments in ALS and FTLD. Frontiers in neuroscience 13:335. doi:10.3389/fnins.2019.00335

40. Igaz LM, Kwong LK, Chen-Plotkin A, Winton MJ, Unger TL, Xu Y, Neumann M, Trojanowski JQ, Lee VM (2009) Expression of TDP-43 C-terminal Fragments in Vitro Recapitulates Pathological Features of TDP-43 Proteinopathies. The Journal of biological chemistry 284 (13):8516-8524. doi:10.1074/jbc.M809462200

41. Balendra R, Isaacs AM (2018) C9orf72-mediated ALS and FTD: multiple pathways to disease. Nature reviews Neurology 14 (9):544-558. doi:10.1038/s41582-018-0047-2 
42. Shi Y, Lin S, Staats KA, Li Y, Chang WH, Hung ST, Hendricks E, Linares GR, Wang Y, Son EY, Wen X, Kisler K, Wilkinson B, Menendez L, Sugawara T, Woolwine P, Huang M, Cowan MJ, Ge B, Koutsodendris N, Sandor KP, Komberg J, Vangoor VR, Senthilkumar K, Hennes V, Seah C, Nelson AR, Cheng TY, Lee SJ, August PR, Chen JA, Wisniewski N, Hanson-Smith V, Belgard TG, Zhang A, Coba M, Grunseich C, Ward ME, van den Berg LH, Pasterkamp RJ, Trotti D, Zlokovic BV, Ichida JK (2018) Haploinsufficiency leads to neurodegeneration in C9ORF72 ALS/FTD human induced motor neurons. Nature medicine 24 (3):313-325. doi:10.1038/nm.4490

43. Ciura S, Lattante S, Le Ber I, Latouche M, Tostivint H, Brice A, Kabashi E (2013) Loss of function of C9orf72 causes motor deficits in a zebrafish model of amyotrophic lateral sclerosis. Annals of neurology 74 (2):180-187. doi:10.1002/ana.23946

44. Liu WJ, Ye L, Huang WF, Guo LJ, Xu ZG, Wu HL, Yang C, Liu HF (2016) p62 links the autophagy pathway and the ubiqutin-proteasome system upon ubiquitinated protein degradation. Cellular \& molecular biology letters 21:29. doi:10.1186/s11658-016-0031-z

45. Jiang P, Mizushima N (2015) LC3- and p62-based biochemical methods for the analysis of autophagy progression in mammalian cells. Methods 75:13-18. doi:10.1016/j.ymeth.2014.11.021

46. Mizushima N (2007) Autophagy: process and function. Genes \& development 21 (22):2861-2873. doi:10.1101/gad.1599207

47. Gal J, Strom AL, Kilty R, Zhang F, Zhu H (2007) p62 accumulates and enhances aggregate formation in model systems of familial amyotrophic lateral sclerosis. The Journal of biological chemistry 282 (15):11068-11077. doi:10.1074/jbc.M608787200

48. Mitsui S, Otomo A, Nozaki M, Ono S, Sato K, Shirakawa R, Adachi H, Aoki M, Sobue G, Shang HF, Hadano S (2018) Systemic overexpression of SQSTM1/p62 accelerates disease onset in a SOD1(H46R)-expressing ALS mouse model. Molecular brain 11 (1):30. doi:10.1186/s13041-0180373-8

49. Tada M, Doi H, Koyano S, Kubota S, Fukai R, Hashiguchi S, Hayashi N, Kawamoto Y, Kunii M, Tanaka K, Takahashi K, Ogawa Y, Iwata R, Yamanaka S, Takeuchi H, Tanaka F (2018) Matrin 3 Is a Component of Neuronal Cytoplasmic Inclusions of Motor Neurons in Sporadic Amyotrophic Lateral Sclerosis. The American journal of pathology 188 (2):507-514. doi:10.1016/j.ajpath.2017.10.007

50. Malik AM, Miguez RA, Li X, Ho YS, Feldman EL, Barmada SJ (2018) Matrin 3-dependent neurotoxicity is modified by nucleic acid binding and nucleocytoplasmic localization. eLife 7. doi:10.7554/eLife.35977

51. Stach L, Freemont PS (2017) The AAA+ ATPase p97, a cellular multitool. The Biochemical journal 474 (17):2953-2976. doi:10.1042/BCJ20160783

52. Johnson JO, Mandrioli J, Benatar M, Abramzon Y, Van Deerlin VM, Trojanowski JQ, Gibbs JR, Brunetti M, Gronka S, Wuu J, Ding J, McCluskey L, Martinez-Lage M, Falcone D, Hernandez DG, Arepalli S, Chong S, Schymick JC, Rothstein J, Landi F, Wang YD, Calvo A, Mora G, Sabatelli M, Monsurro MR, Battistini S, Salvi F, Spataro R, Sola P, Borghero G, Galassi G, Scholz SW, Taylor JP, Restagno G, Chio 
A, Traynor BJ (2010) Exome sequencing reveals VCP mutations as a cause of familial ALS. Neuron 68 (5):857-864. doi:10.1016/j.neuron.2010.11.036

53. Kustermann M, Manta L, Paone C, Kustermann J, Lausser L, Wiesner C, Eichinger L, Clemen CS, Schroder R, Kestler HA, Sandri M, Rottbauer W, Just S (2018) Loss of the novel Vcp (valosin containing protein) interactor Washc4 interferes with autophagy-mediated proteostasis in striated muscle and leads to myopathy in vivo. Autophagy 14 (11):1911-1927.

doi:10.1080/15548627.2018.1491491

54. Yamaguchi A, Takanashi K (2016) FUS interacts with nuclear matrix-associated protein SAFB1 as well as Matrin3 to regulate splicing and ligand-mediated transcription. Scientific reports 6:35195. doi:10.1038/srep35195

55. Ishigaki S, Sobue G (2018) Importance of Functional Loss of FUS in FTLD/ALS. Frontiers in molecular biosciences 5:44. doi:10.3389/fmolb.2018.00044

56. Niwa J, Yamada S, Ishigaki S, Sone J, Takahashi M, Katsuno M, Tanaka F, Doyu M, Sobue G (2007) Disulfide bond mediates aggregation, toxicity, and ubiquitylation of familial amyotrophic lateral sclerosis-linked mutant SOD1. The Journal of biological chemistry 282 (38):28087-28095. doi:10.1074/jbc.M704465200

57. Rosen DR, Siddique T, Patterson D, Figlewicz DA, Sapp P, Hentati A, Donaldson D, Goto J, O'Regan JP, Deng HX, et al. (1993) Mutations in $\mathrm{Cu} / \mathrm{Zn}$ superoxide dismutase gene are associated with familial amyotrophic lateral sclerosis. Nature 362 (6415):59-62. doi:10.1038/362059a0

58. Korenbaum E, Nordberg P, Bjorkegren-Sjogren C, Schutt CE, Lindberg U, Karlsson R (1998) The role of profilin in actin polymerization and nucleotide exchange. Biochemistry 37 (26):9274-9283. doi:10.1021/bi9803675

59. Wu CH, Fallini C, Ticozzi N, Keagle PJ, Sapp PC, Piotrowska K, Lowe P, Koppers M, McKenna-Yasek D, Baron DM, Kost JE, Gonzalez-Perez P, Fox AD, Adams J, Taroni F, Tiloca C, Leclerc AL, Chafe SC, Mangroo D, Moore MJ, Zitzewitz JA, Xu ZS, van den Berg LH, Glass JD, Siciliano G, Cirulli ET, Goldstein DB, Salachas F, Meininger V, Rossoll W, Ratti A, Gellera C, Bosco DA, Bassell GJ, Silani V, Drory VE, Brown RH, Jr., Landers JE (2012) Mutations in the profilin 1 gene cause familial amyotrophic lateral sclerosis. Nature 488 (7412):499-503. doi:10.1038/nature11280

60. Stifanese R, Averna M, De Tullio R, Pedrazzi M, Milanese M, Bonifacino T, Bonanno G, Salamino F, Pontremoli S, Melloni E (2014) Role of calpain-1 in the early phase of experimental ALS. Archives of biochemistry and biophysics 562:1-8. doi:10.1016/j.abb.2014.08.006

61. Rao MV, Campbell J, Palaniappan A, Kumar A, Nixon RA (2016) Calpastatin inhibits motor neuron death and increases survival of hSOD1(G93A) mice. Journal of neurochemistry 137 (2):253-265. doi:10.1111/jnc.13536

62. Riedl SJ, Shi Y (2004) Molecular mechanisms of caspase regulation during apoptosis. Nature reviews Molecular cell biology 5 (11):897-907. doi:10.1038/nrm1496

63. Inoue S, Browne G, Melino G, Cohen GM (2009) Ordering of caspases in cells undergoing apoptosis by the intrinsic pathway. Cell death and differentiation 16 (7):1053-1061. doi:10.1038/cdd.2009.29 
64. Inoue H, Tsukita K, Iwasato T, Suzuki Y, Tomioka M, Tateno M, Nagao M, Kawata A, Saido TC, Miura M, Misawa H, Itohara S, Takahashi R (2003) The crucial role of caspase-9 in the disease progression of a transgenic ALS mouse model. The EMBO journal 22 (24):6665-6674. doi:10.1093/emboj/cdg634

65. Li M, Ona VO, Guegan C, Chen M, Jackson-Lewis V, Andrews LJ, Olszewski AJ, Stieg PE, Lee JP, Przedborski S, Friedlander RM (2000) Functional role of caspase-1 and caspase-3 in an ALS transgenic mouse model. Science 288 (5464):335-339

66. Pasinelli P, Houseweart MK, Brown RH, Jr., Cleveland DW (2000) Caspase- 1 and -3 are sequentially activated in motor neuron death in $\mathrm{Cu}, \mathrm{Zn}$ superoxide dismutase-mediated familial amyotrophic lateral sclerosis. Proceedings of the National Academy of Sciences of the United States of America 97 (25):13901-13906. doi:10.1073/pnas.240305897

67. Hogg MC, Mitchem MR, Konig HG, Prehn JH (2016) Caspase 6 has a protective role in SOD1(G93A) transgenic mice. Biochimica et biophysica acta 1862 (6):1063-1073.

doi:10.1016/j.bbadis.2016.03.006

68. (!!! INVALID CITATION !!!).

69. Bootman MD, Chehab T, Bultynck G, Parys JB, Rietdorf K (2018) The regulation of autophagy by calcium signals: Do we have a consensus? Cell calcium 70:32-46. doi:10.1016/j.ceca.2017.08.005

70. Engedal N, Torgersen ML, Guldvik IJ, Barfeld SJ, Bakula D, Saetre F, Hagen LK, Patterson JB, ProikasCezanne T, Seglen PO, Simonsen A, Mills IG (2013) Modulation of intracellular calcium homeostasis blocks autophagosome formation. Autophagy 9 (10):1475-1490. doi:10.4161/auto.25900

71. Ganley IG, Wong PM, Gammoh N, Jiang X (2011) Distinct autophagosomal-lysosomal fusion mechanism revealed by thapsigargin-induced autophagy arrest. Molecular cell 42 (6):731-743. doi:10.1016/j.molcel.2011.04.024

72. Evans CS, Holzbaur ELF (2019) Autophagy and mitophagy in ALS. Neurobiology of disease 122:3540. doi:10.1016/j.nbd.2018.07.005

73. Nguyen DKH, Thombre R, Wang J (2019) Autophagy as a common pathway in amyotrophic lateral sclerosis. Neuroscience letters 697:34-48. doi:10.1016/j.neulet.2018.04.006

74. Demarchi F, Bertoli C, Copetti T, Tanida I, Brancolini C, Eskelinen EL, Schneider C (2006) Calpain is required for macroautophagy in mammalian cells. The Journal of cell biology 175 (4):595-605. doi:10.1083/jcb.200601024

75. Chua BT, Guo K, Li P (2000) Direct cleavage by the calcium-activated protease calpain can lead to inactivation of caspases. The Journal of biological chemistry 275 (7):5131-5135. doi:10.1074/jbc.275.7.5131

76. Gafni J, Cong X, Chen SF, Gibson BW, Ellerby LM (2009) Calpain-1 cleaves and activates caspase-7. The Journal of biological chemistry 284 (37):25441-25449. doi:10.1074/jbc.M109.038174

77. Maiuri MC, Zalckvar E, Kimchi A, Kroemer G (2007) Self-eating and self-killing: crosstalk between autophagy and apoptosis. Nature reviews Molecular cell biology 8 (9):741-752. doi:10.1038/nrm2239 
78. Thorburn A (2008) Apoptosis and autophagy: regulatory connections between two supposedly different processes. Apoptosis : an international journal on programmed cell death 13 (1):1-9. doi:10.1007/s10495-007-0154-9

79. Wu H, Che X, Zheng Q, Wu A, Pan K, Shao A, Wu Q, Zhang J, Hong Y (2014) Caspases: a molecular switch node in the crosstalk between autophagy and apoptosis. International journal of biological sciences 10 (9):1072-1083. doi:10.7150/ijbs.9719

80. Ju JS, Fuentealba RA, Miller SE, Jackson E, Piwnica-Worms D, Baloh RH, Weihl CC (2009) Valosincontaining protein (VCP) is required for autophagy and is disrupted in VCP disease. The Journal of cell biology 187 (6):875-888. doi:10.1083/jcb.200908115

81. Nassif M, Woehlbier U, Manque PA (2017) The Enigmatic Role of C9ORF72 in Autophagy. Frontiers in neuroscience 11:442. doi:10.3389/fnins.2017.00442

82. Yeo BK, Hong CJ, Chung KM, Woo H, Kim K, Jung S, Kim EK, Yu SW (2016) Valosin-containing protein is a key mediator between autophagic cell death and apoptosis in adult hippocampal neural stem cells following insulin withdrawal. Molecular brain 9:31. doi:10.1186/s13041-016-0212-8

\section{Figures}




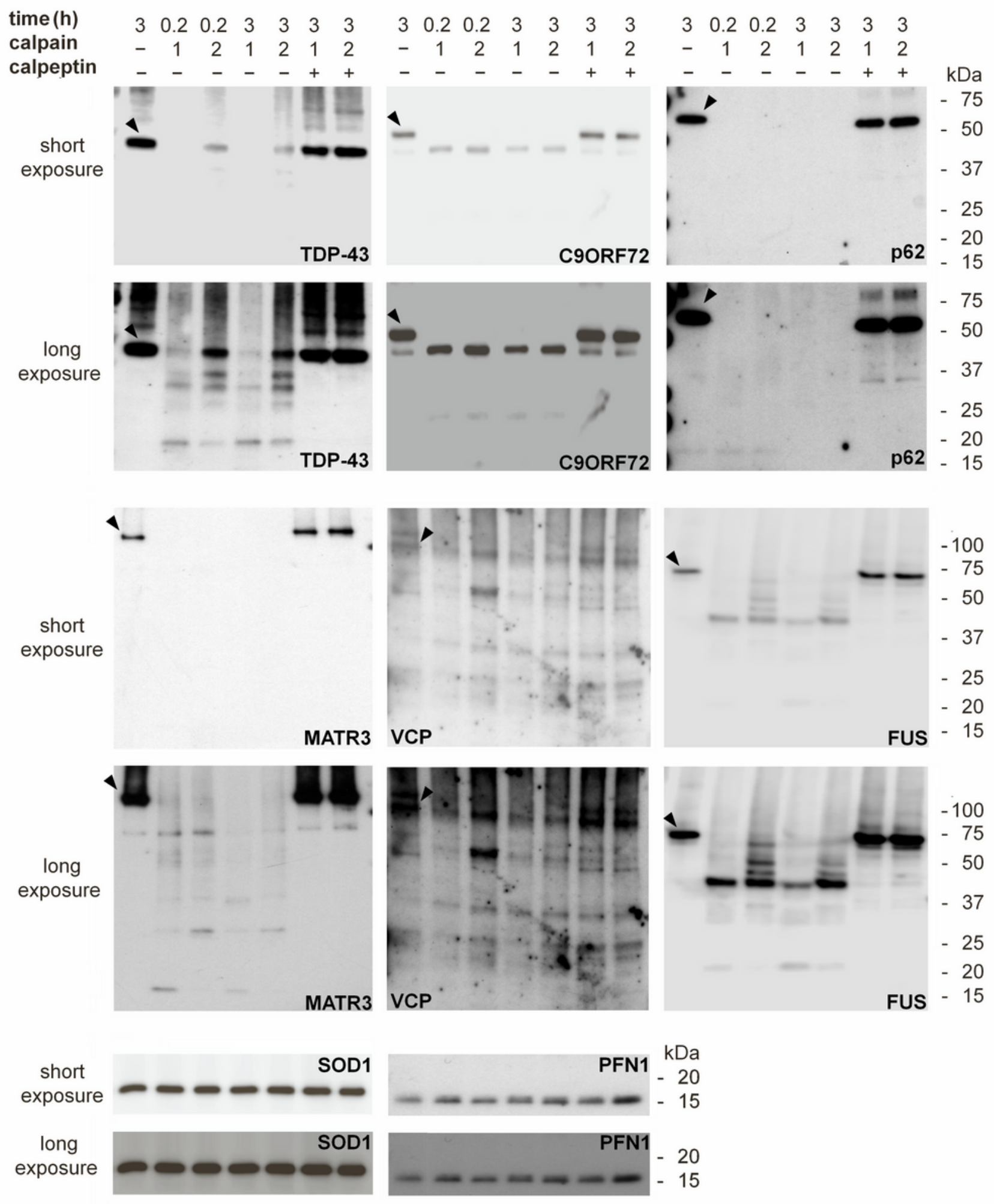

\section{Figure 1}

Calpain cleavage of proteins coded by genes linked to ALS. Western immunoblot analysis of the eight proteins here considered in SK-N-BE(2) cell lysate separately incubated with $2 \mathrm{U}$ of recombinant active human calpains- 1 or -2 , at $37^{\circ} \mathrm{C}$ for 10 or 180 minutes. Incubation of the cell lysate in presence of $20 \mathrm{mM}$ calpeptin, a calpain inhibitor, was also performed. Blots are representative of three independent experiments. The arrowhead indicates the immunoreactive band corresponding to the full-length protein 


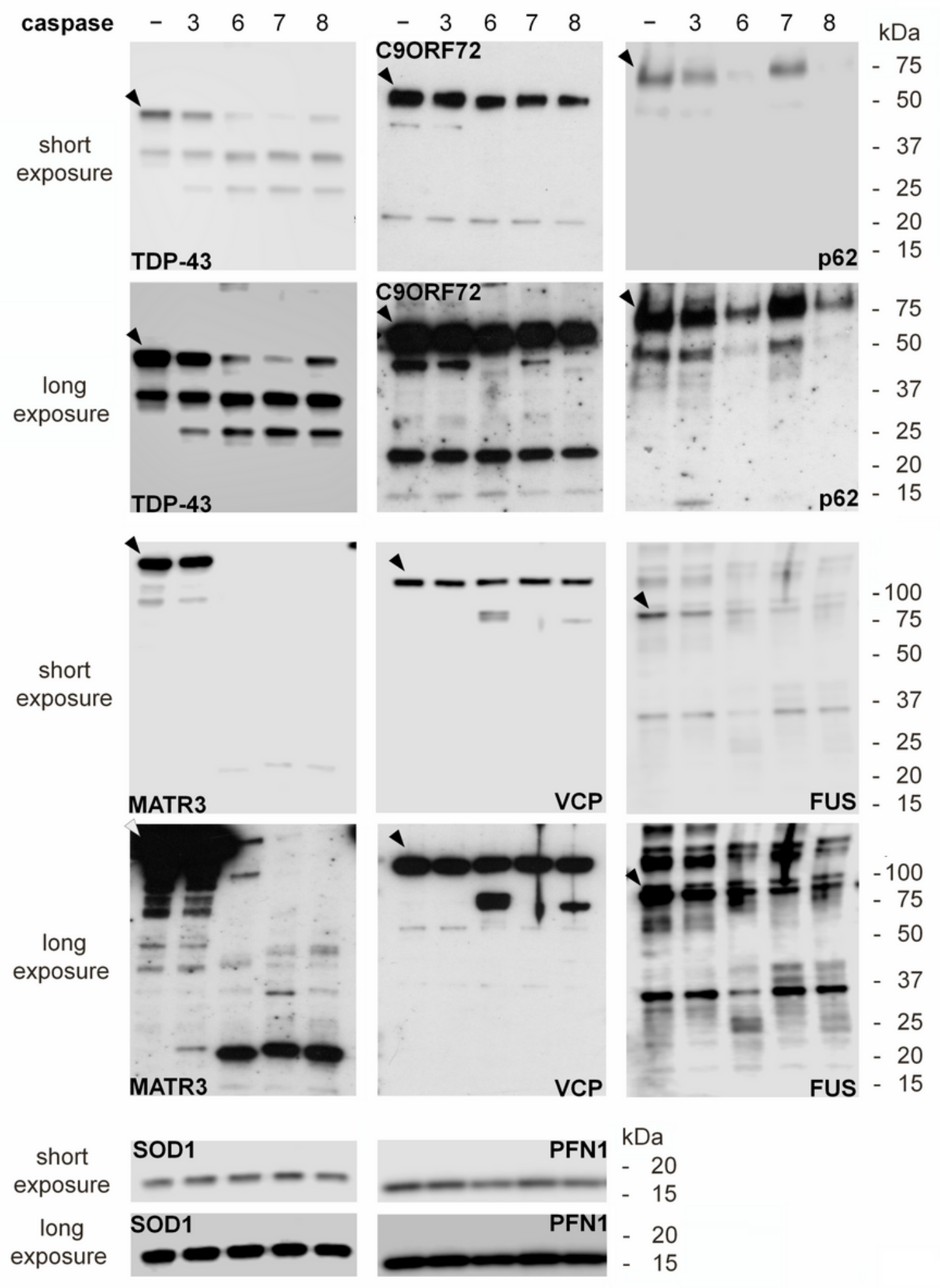

\section{Figure 2}

Caspase cleavage of proteins coded by genes linked to ALS. Western immunoblot analysis of the eight proteins here considered in SK-N-BE(2) cell lysate separately incubated with $2 \mathrm{U}$ of recombinant active human caspases $-3,6,7$ or -8 , for $3 \mathrm{~h}$ at $37^{\circ} \mathrm{C}$. Blots are representative of three independent experiments. The arrowhead indicates the immunoreactive band corresponding to the full-length protein 


$$
\text { C } \frac{\text { lon }}{15} \frac{\mathrm{Tg}}{15}
$$
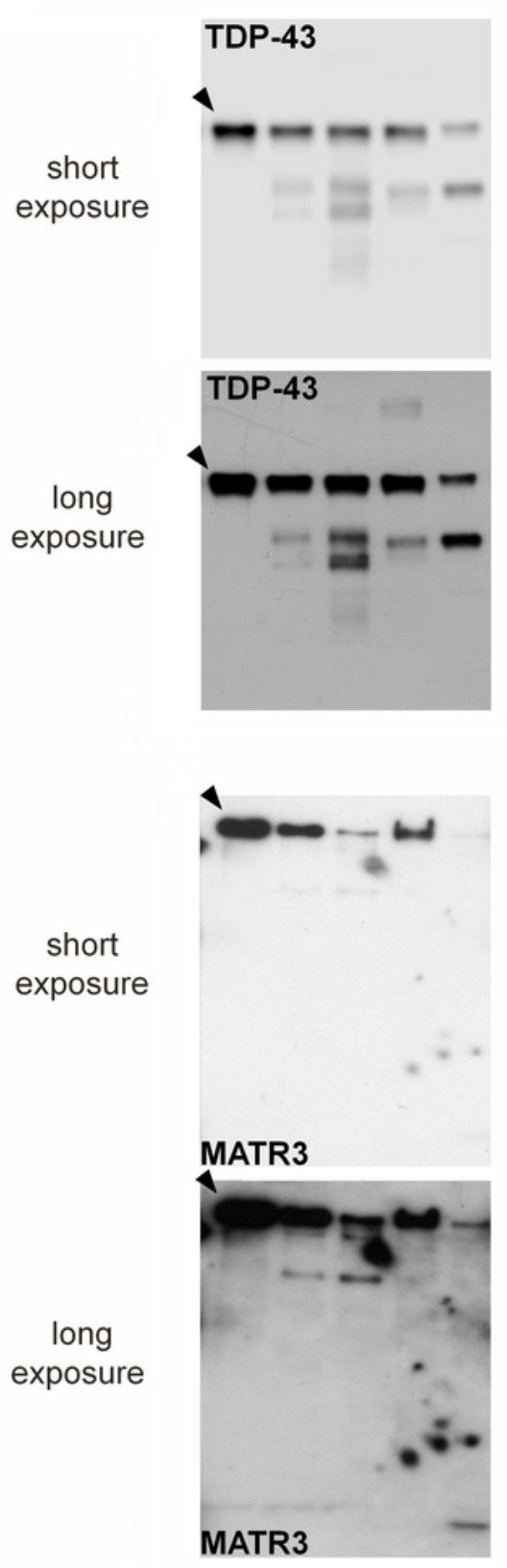

short
exposure
long
exposure
C $\frac{\text { Ion }}{15} \frac{\mathrm{Tg}}{15}$
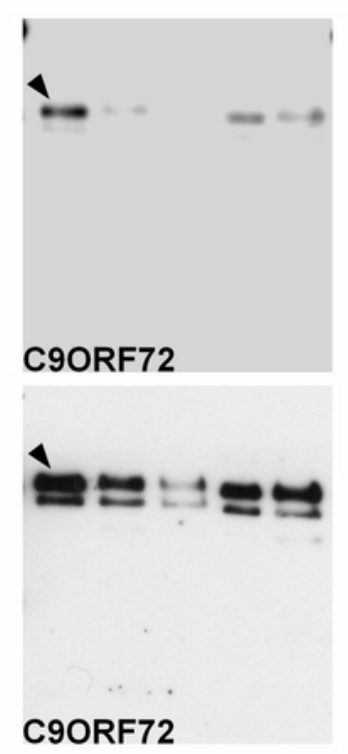

C9ORF72

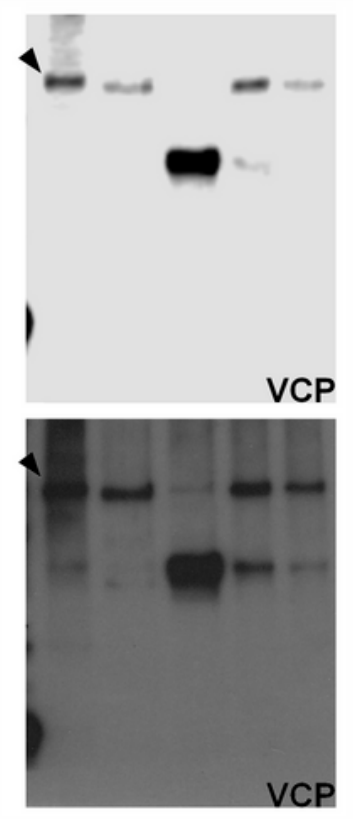

$\mathrm{kDa}$

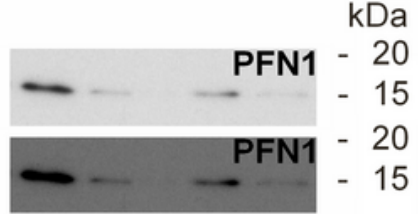
C $\frac{\text { Ion }}{15} \frac{\mathrm{Tg}}{15}$

$\mathrm{kDa}$
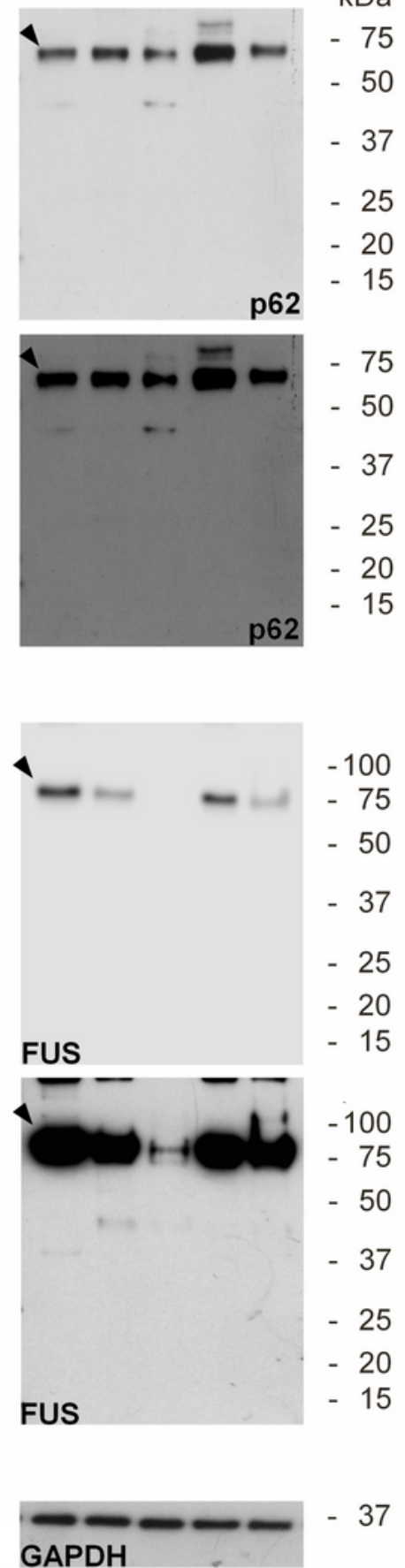

$-37$

\section{Figure 3}

Effects of increased cytoplasmic Ca2+ in SK-N-BE(2) cell line. Western immunoblot analysis of the eight proteins here considered in SK-N-BE(2) cell line treated with ionomycin (lon) or thapsigargin ( $\mathrm{Tg}$ ) at two different concentrations ( $1 \mathrm{mM}$ and $5 \mathrm{mM}$ ) for $24 \mathrm{~h}$. GAPDH expression is used as a measure of equal protein loading. The arrowhead indicates the immunoreactive band corresponding to the full-length protein. Blots are representative of three independent experiments. $\mathrm{C}=$ control, untreated cells 

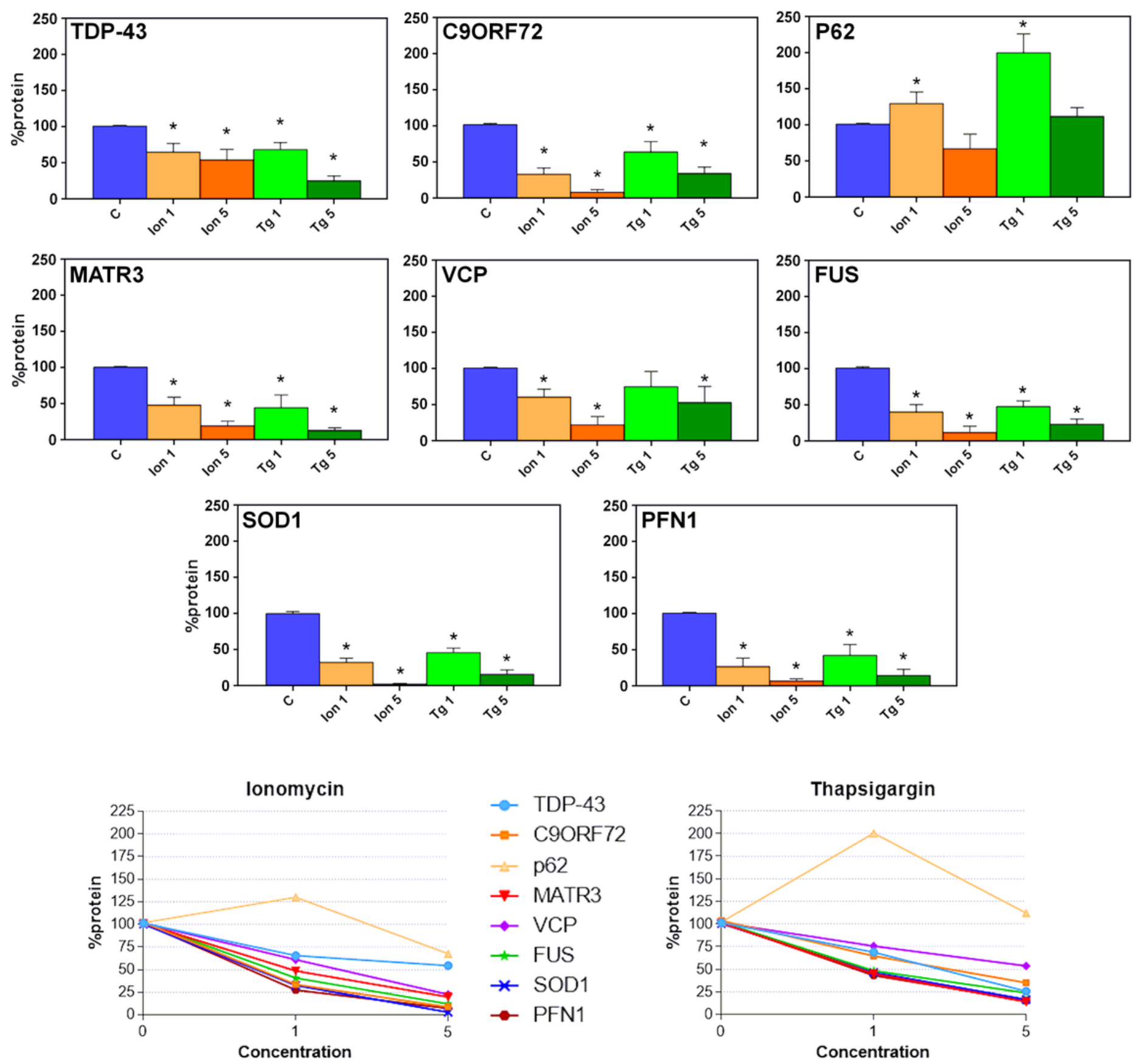

\section{Figure 4}

Trend of the eight proteins here analysed in SK-N-BE(2) cells forced to increase their cytoplasmic Ca2+ levels. The bar graphs illustrate the expression of each protein treated with ionomycin (lon) or thapsigargin ( $\mathrm{Tg}$ ) compared to the expression in untreated cells (C), with the latter being arbitrarily considered as $100 \%$. The line graphs show a comparison among the quantity trends of the proteins here analysed for treatments with ionomycin or thapsigargin. Data are representative of three independent experiments. ${ }^{*} p<0.05$; error bars $=$ standard deviations 
C $\frac{\text { Ion }}{15} \frac{\mathrm{Tg}}{15}$

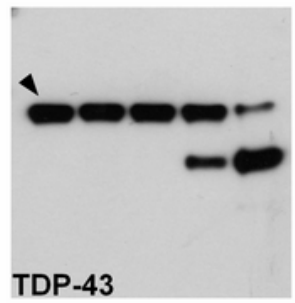

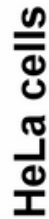

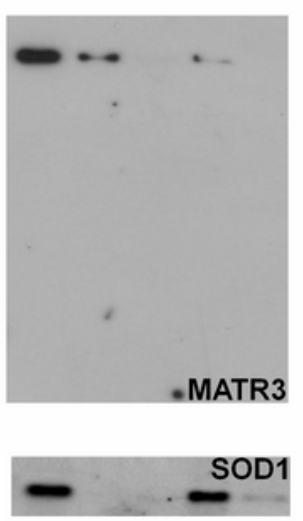

C $\frac{\text { lon }}{15} \frac{\mathrm{Tg}}{15}$

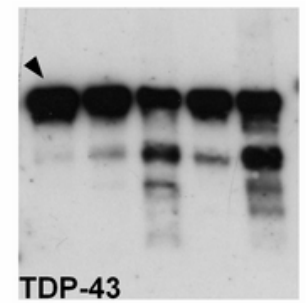

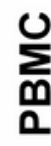

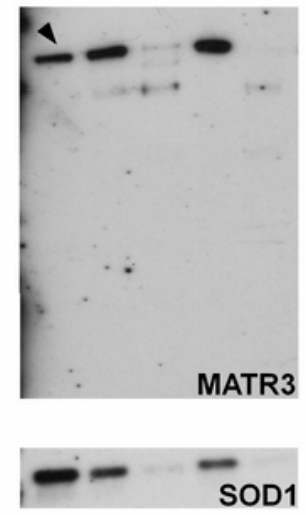

C $\frac{\text { Ion }}{15} \frac{\mathrm{Tg}}{15}$
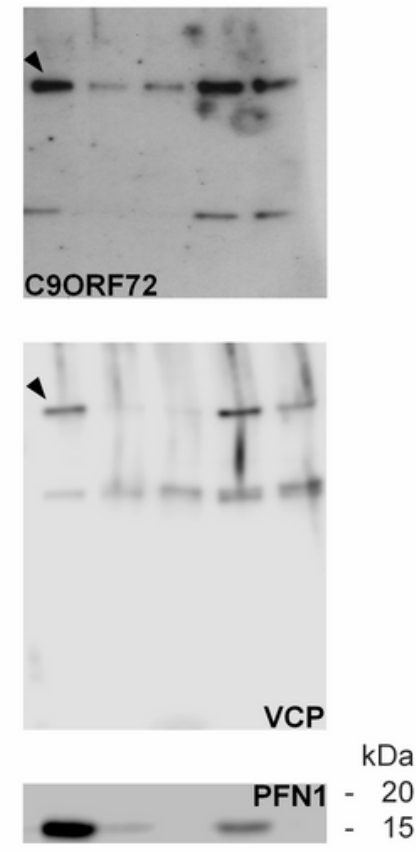

C $\frac{\text { Ion }}{15} \frac{\mathrm{Tg}}{15}$
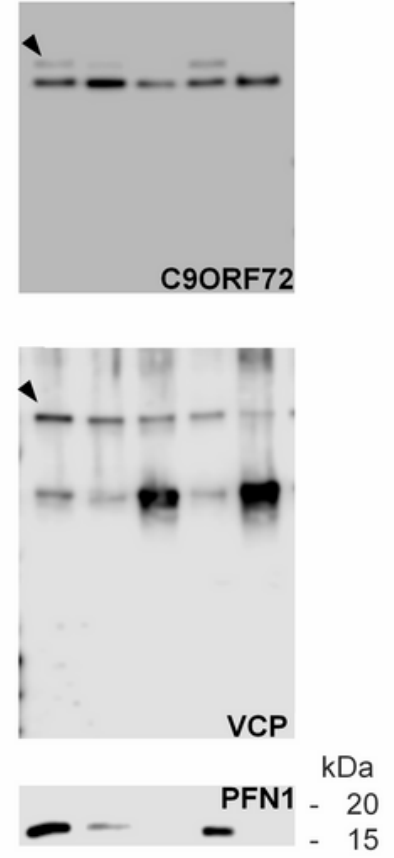

C $\frac{\text { Ion }^{-}}{15} \frac{\mathrm{Tg}}{15}$ $\mathrm{kDa}$
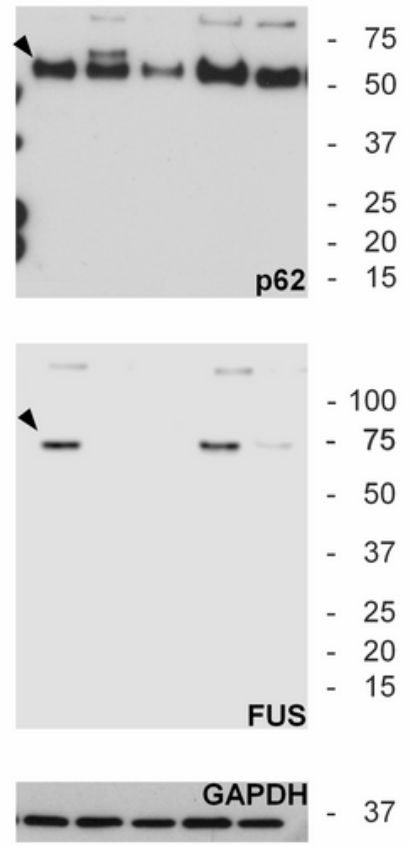

C $\frac{\text { Ion }}{15} \frac{\mathrm{Tg}}{15} \mathrm{kDa}$
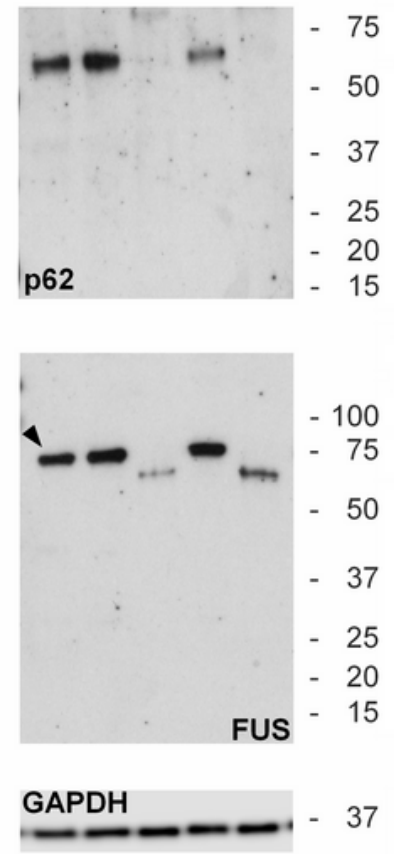

Figure 5

Effects of increased cytoplasmic Ca2+ in HeLa cell line and in peripheral blood mononuclear cells (PBMC). Western immunoblot analysis of the eight proteins here considered in HeLa as well as PBMC treated with ionomycin (Ion) or thapsigargin ( $\mathrm{Tg}$ ) at two different concentrations ( $1 \mathrm{mM}$ and $5 \mathrm{mM}$ ) for 24 h. GAPDH expression is used as a measure of equal protein loading. The arrowhead indicates the 
immunoreactive band corresponding to the full-length protein. Blots are representative of three independent experiments. $\mathrm{C}=$ control, untreated cells

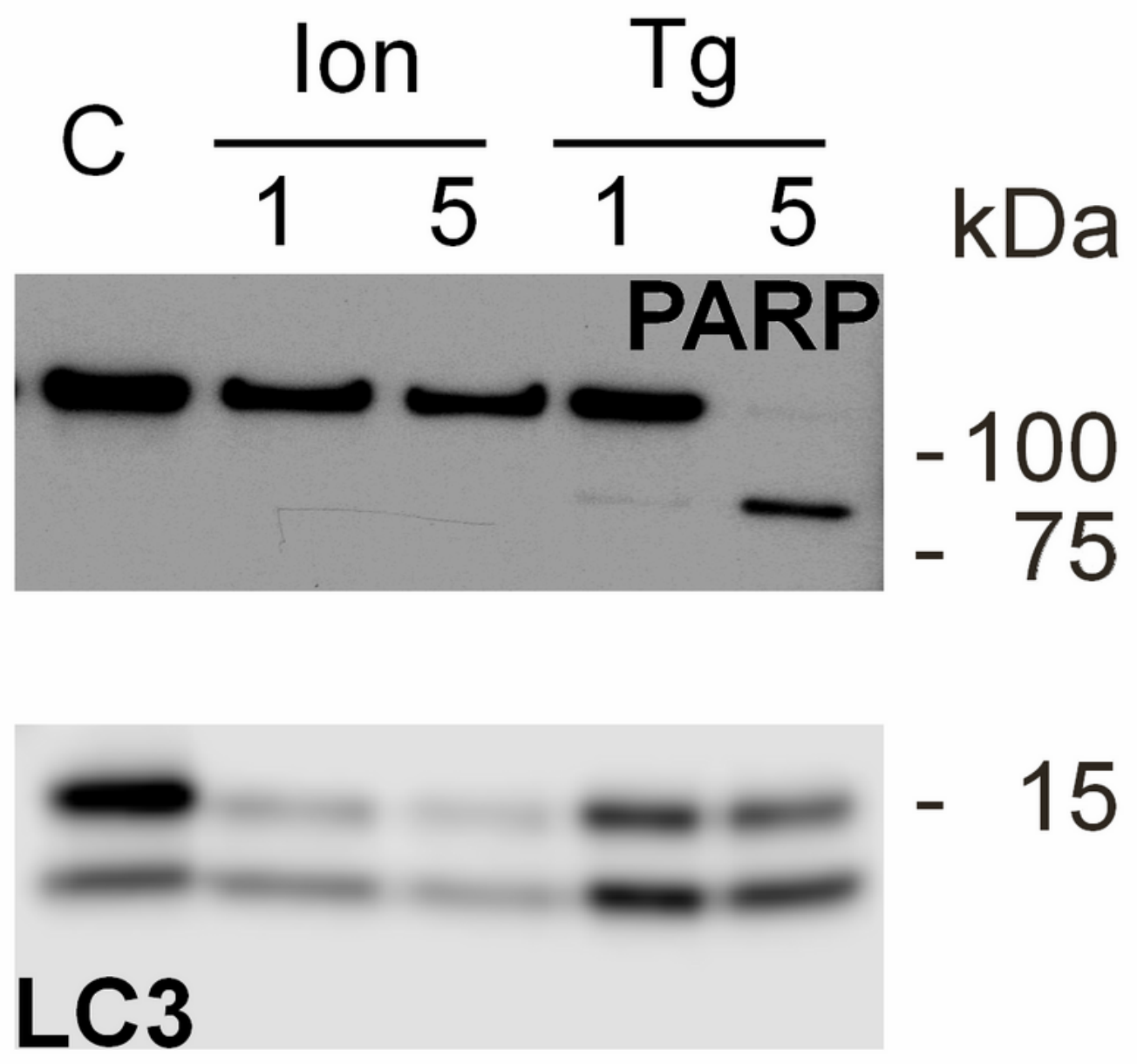

\section{$\begin{array}{lllll}1.7 & 0.50 & 0.27 & 0.91 & 0.79\end{array}$}

\section{GAPDH}

$-37$

Figure 6

Effects of increased cytoplasmic Ca2+ on proteins not directly linked to ALS. Western immunoblot analysis of a protein linked to apoptosis (PARP) and a protein linked to autophagy (LC3) in SK-N-BE(2) cell line treated with ionomycin (Ion) or thapsigargin (Tg) at two different concentrations ( $1 \mathrm{mM}$ and 5 
$\mathrm{mM}$ ) at $37^{\circ} \mathrm{C}$ for $24 \mathrm{~h}$. The ratio between LC3-I (non-lipidated form) and LC-II (lipidated form) is reported. GAPDH expression is used as a measure of equal protein loading. Blots are representative of three independent experiments

a

$\frac{\text { Ctrl }}{2 \mathrm{~h} 8 \mathrm{~h} 24 \mathrm{~h}} \frac{\operatorname{lon} 1}{2 \mathrm{~h} 8 \mathrm{~h} 24 \mathrm{~h}} \frac{\operatorname{Tg} 1}{2 \mathrm{~h} 8 \mathrm{~h} 24 \mathrm{~h}}$

TDP-43

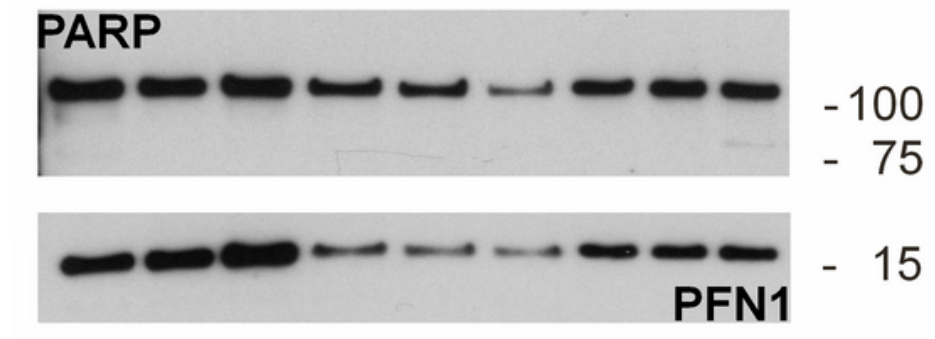

$-100$

$-75$

$-50$

$-37$

$-25$

$-20$

$-15$ $\frac{\text { Ctrl }}{2 \mathrm{~h} 8 \mathrm{~h} 24 \mathrm{~h}} \frac{\operatorname{lon} 1}{2 \mathrm{~h} 8 \mathrm{~h} 24 \mathrm{~h}} \frac{\operatorname{Tg} 1}{2 \mathrm{~h} 8 \mathrm{~h} 24 \mathrm{~h}}$

p62
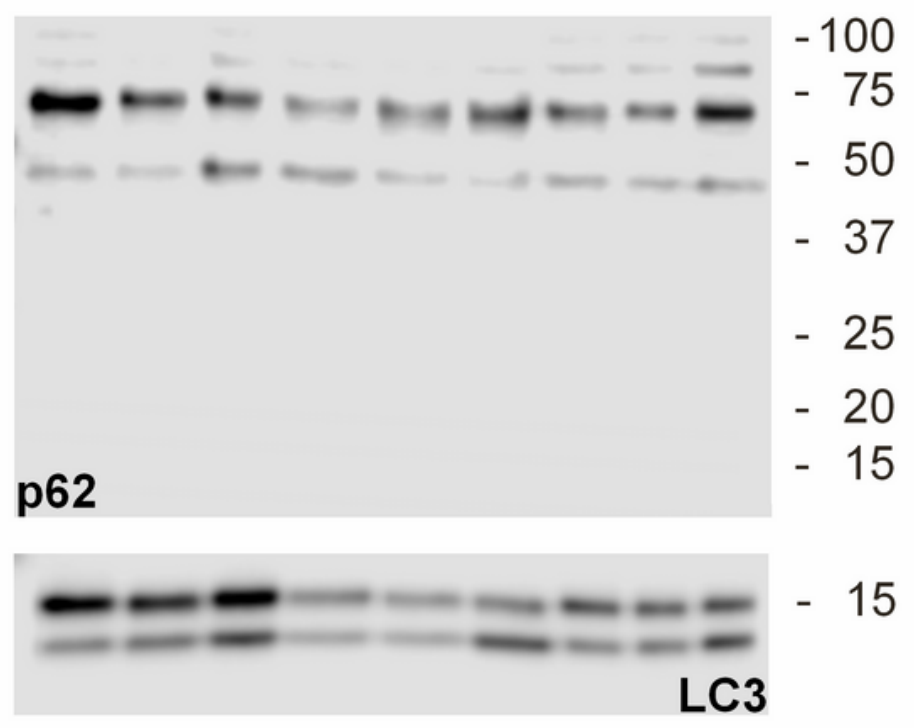

$-37$

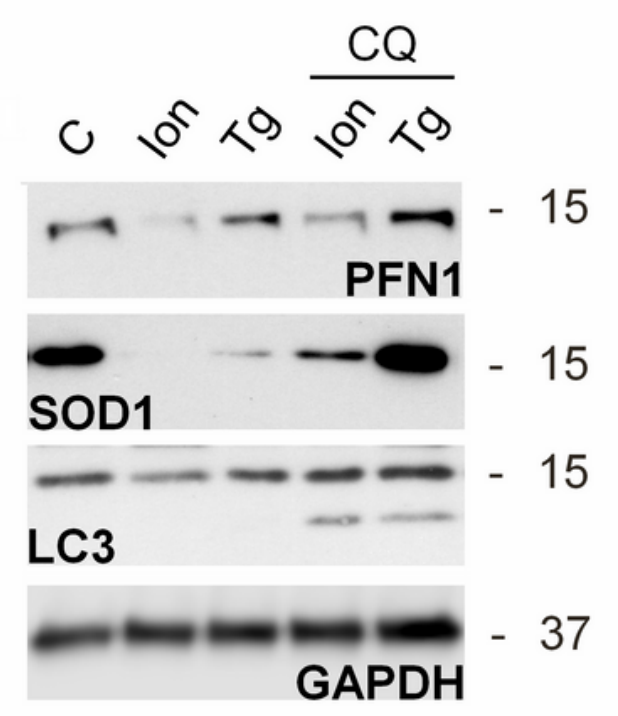

Figure 7

effects of intracellular Ca2+ accumulation over time as well as in presence of chloroquine in SK-N-BE(2) cells. Western immunoblot analysis of TDP-43, p62/SQSTM1, PFN1, PARP and LC3 in SK-N-BE(2) cell line 
treated with $1 \mathrm{mM}$ ionomycin (Ion) or thapsigargin ( $\mathrm{Tg}$ ) for 2, 8 and $24 \mathrm{~h} \mathrm{(a).} \mathrm{Western} \mathrm{immunoblot}$ analysis of TDP-43, p62/SQSTM1, PFN1, SOD1, PARP and LC3 in SK-N-BE(2) cell line treated with $1 \mathrm{mM}$ ionomycin (Ion) or thapsigargin ( $\mathrm{Tg}$ ) for $2 \mathrm{~h}$ with and without preincubation with $100 \mu \mathrm{M}$ chloroquine (CQ) (b). GAPDH expression is used as a measure of equal protein loading. Blots are representative of three independent experiments

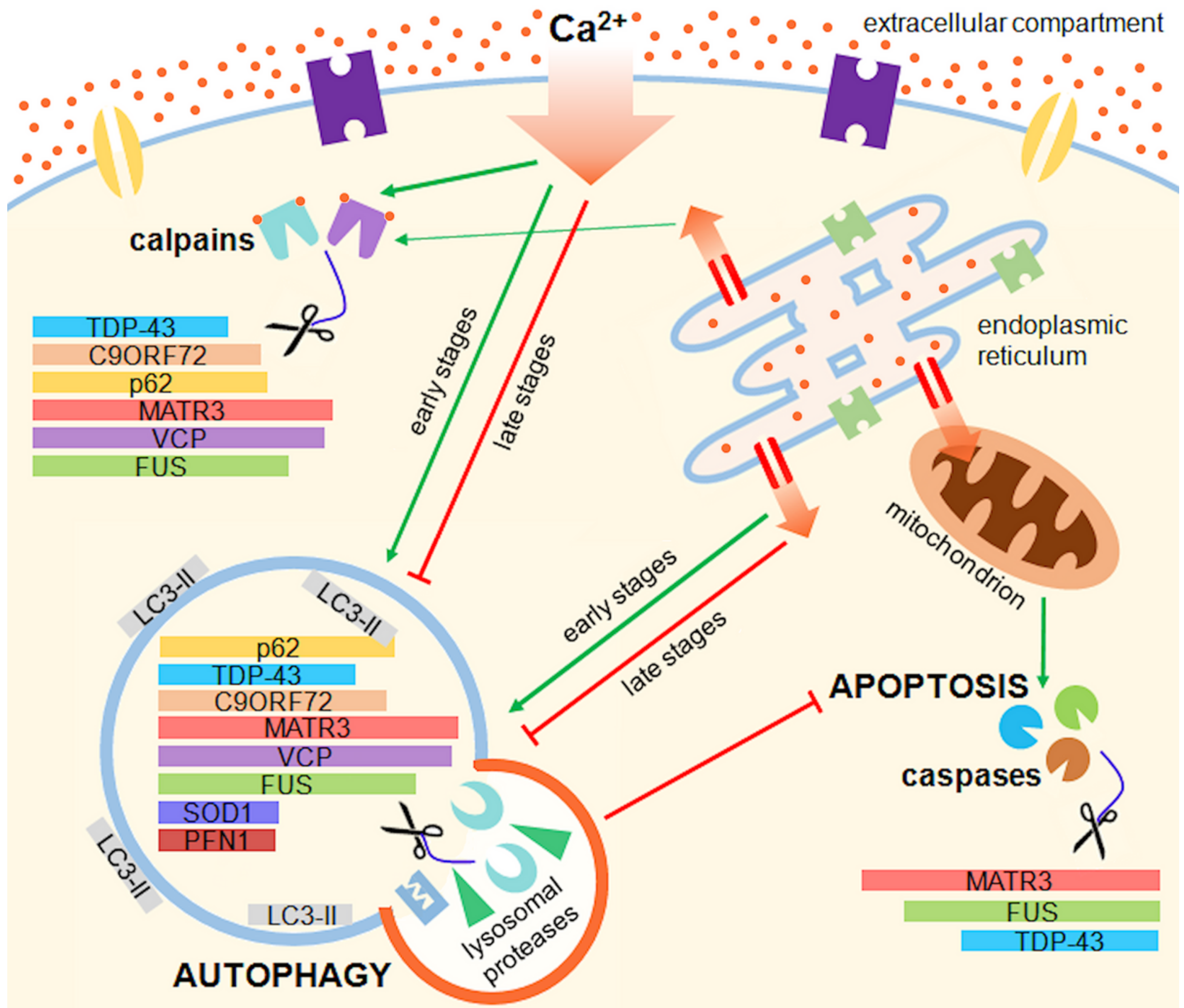

\section{Figure 8}

Effects of intracellular Ca2+ accumulations on proteins linked to ALS. Excessive influx as well as abnormal release from intracellular storages (i.e., endoplasmic reticulum) of $\mathrm{Ca} 2+$ causes the activation of proteolytic processes including calpain and caspase cleavage as well as autophagy. In the early stages, the raise in intracellular $\mathrm{Ca} 2+$ levels triggers the activation of calpains and favours autophagy. Over a longer period, intracellular $\mathrm{Ca} 2+$ accumulation leads to a block of the autophagic process (which 
is accompanied by an increase in p62/SQSTM1 levels), which, in turn, results in the activation of apoptotic caspases. Apoptosis can also be triggered by $\mathrm{Ca} 2+$ accumulation in mitochondria 